\title{
51. PETROLOGY AND GEOCHEMISTRY OF IGNEOUS ROCKS, DSDP LEG 37
}

\author{
M.F.J. Flower, P.T. Robinson,' ${ }^{1}$ H.-U. Schmincke, and W. Ohnmacht, Institut für Mineralogie der Ruhr- \\ Universität, 463 Bochum, West Germany
}

\section{INTRODUCTION}

Leg 37 of the Deep Sea Drilling Project was successful in its prime objective of deep penetration into acoustic basement in the mid-Atlantic Ocean. A total of 1477 meters of basement was drilled at four sites $(332,333,334$, and 335$)$ with a maximum penetration of 583 meters in Hole 332B. Shipboard studies of the drilled rocks revealed unexpected variations in lithology, chemical composition, and paleomagnetic stratigraphy at three of the four sites.

We have undertaken a detailed geochemical study of these rocks in order to: (1) identify and characterize primary magmas at each site, (2) determine the extent and nature of shallow level fractionation beneath the median rift, (3) determine the relationship between magmatic evolution and the eruptive buildup of layer 2 , (4) determine the geochemical and geothermal evolution of the sub rift melting zone.

The drilled sections of Leg 37 also provide a unique opportunity to evaluate proposed large-scale physical processes such as "mantle plumes" and "hot spots" by reference to secular chemical variations both within and between holes at the four sites, representing a time span of approximately 10-12 m.y. Major, minor, and trace elements were determined for 133 whole-rock specimens from each of the five drilled sections. These are reported in Chapters 2, 3, 4, and 5 (this volume). The main objectives are to identify coherent chemical groups, to determine interrelationships of groups in terms of fractional crystallization and partial fusion of the upper mantle, and to observe secular variations in magma compositions.

Chemical effects due to halmyrolysis and postconsolidation alteration processes are described and discussed separately (Robinson et al., Chapter 61, this volume). It should be noted that the analyses reported here have not been corrected for $\mathrm{CaCO}_{3}$ and $\mathrm{MgCO}_{3}$ introduced by percolating solutions.

Whole-rock analyses were carried out by X-ray fluorescence (except for $\mathrm{FeO}, \mathrm{Na}_{2} \mathrm{O}, \mathrm{H}_{2} \mathrm{O}$, and $\mathrm{CO}_{2}$ ) at Imperial College, London (Holes 332B, 333A, and 334) and the Ruhr-Universität, Bochum (Holes $332 \mathrm{~A}$ and 335). Mineral compositions were determined by electron microprobe at the E.T.H., Zurich and Imperial College. Analyses of interlaboratory standards are given in Wright (Chapter 10, this volume).

\footnotetext{
'Permanent address: Department of Earth Sciences, University of California, Riverside, California.
}

\section{CHEMICAL VARIATION OF DRILLED ROCKS}

Magma groups have been defined from the wholerock chemical analyses in terms of major element oxides. The groups are defined on the basis of chemical affinity and include not only rocks of similar chemistry, but also those whose compositions can be related by simple addition or subtraction of observed phenocryst phases. The important discriminants are $\mathrm{Al}_{2} \mathrm{O}_{3}, \mathrm{TiO}_{2}$, and $\mathrm{FeO}$ for any given $\mathrm{MgO}$ content. In identifying compositional groups analyses reflecting the effects of alteration (high $\mathrm{H}_{2} \mathrm{O}$ and $\mathrm{CO}_{2}$ contents) were not included. Thus, each group so defined should a priori represent an independent low pressure fractionation system, whereas variation between groups must be explained by variable parental magma compositions.

These groups are described and discussed for each of the five major holes drilled on Leg 37 (332A, 332B, $333 \mathrm{~A}, 334$, and 335) in terms of their major and trace element geochemistry, phenocryst and groundmass mineralogy, and stratigraphy. Preceding this is a brief evaluation of the chemistry of fresh glass cooling rinds. Glass compositional groups have been notated alphabetically and whole-rock groups numerically to avoid confusion. Average chemical compositions of glass groups are given in Table 1 and whole-rock groups in Table 2, whereas average compositions of mineral phases in individual magma groups are given in Tables $3,4,5$, and 6 .

\section{Chemistry of Glass Cooling Rinds}

Glass rinds are most common in Holes 332A, 332B, Site 335, and the upper eruptive part of Site 334. From shipboard lithologic studies we conclude that virtually all of the glassy zones are associated with erupted magmas, especially pillow sequences. The glass analyses are valuable for four main reasons: (1) they reflect the lower limit of $\mathrm{MgO}$ content in primitive liquids, (2) they show none of the effects of crystal accumulation evidenced by whole-rock compositions, (3) they give the most reliable indication of magmatic $\mathrm{K}_{2} \mathrm{O}$ content, (4) they provide compositional reference groups against which whole-rock analyses may be compared in order to identify low pressure fractionation processes.

For Leg 37 samples 102 glass analyses by electron microprobe are available -40 from Dalhousie University (F. Aumento) and 62 from the Smithsonian Institution (W.G. Melson). For this report we have selected the Smithsonian data for comparison because they correspond most closely with associated whole-rock compositions and give greater stratigraphic coverage. 
TABLE 1

Average Compositions of Leg 37 Glass Groups Identified by T.L. Wright for Analyses by W.G. Melson

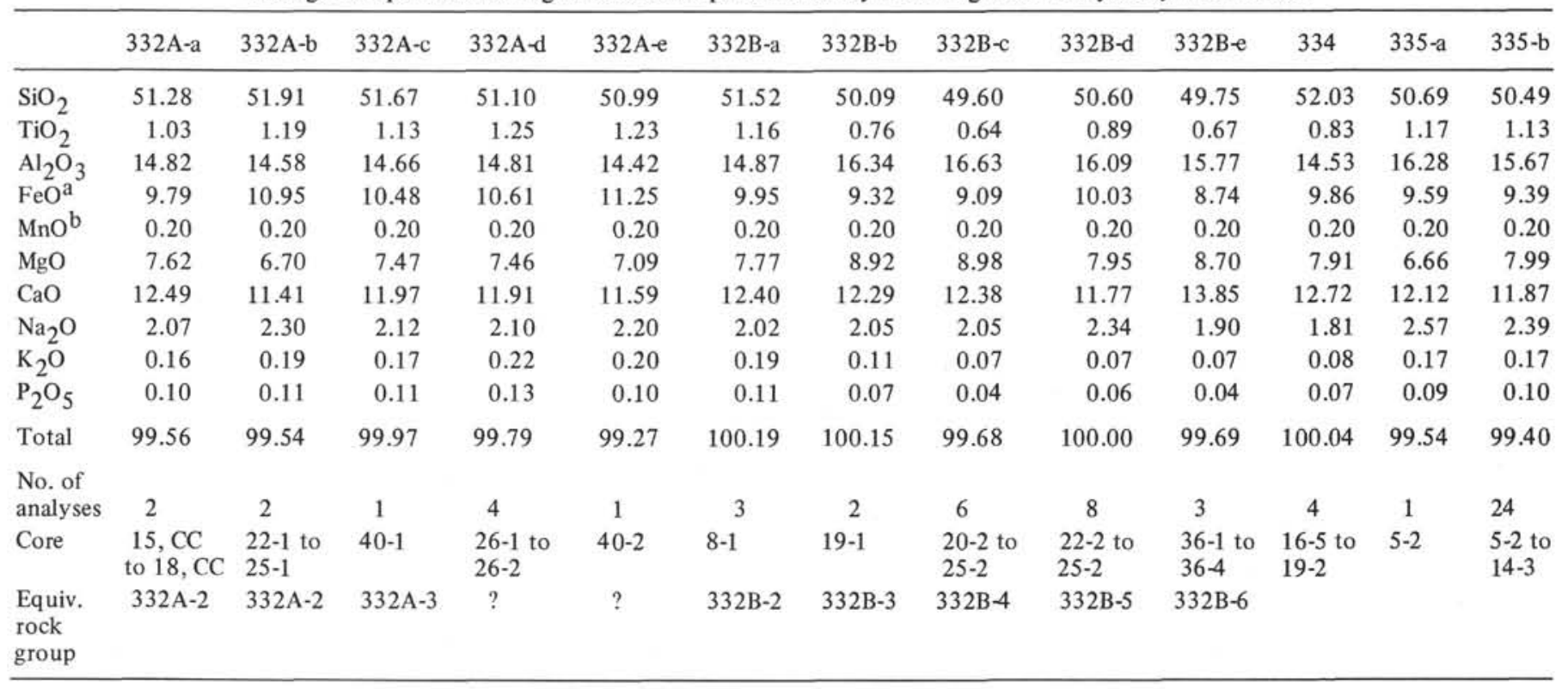

${ }^{\mathrm{a}}$ Total Fe-oxide.

${ }^{\mathrm{b}}$ Assumed $\mathrm{MnO}$.

Normative glass compositions, along with wholerock analyses, are plotted on the Tilley-Muir diagram (Figure 1) and show Leg 37 basalts to be exclusively olivine and quartz tholeiites. Chemical groupings of the Smithsonian glass analyses were made by T.L. Wright by means of a chemical sorting program using specified element tolerances (see Melson et al., in press). These groups are shown with whole-rock data on $\mathrm{MgO}$ variation diagrams in Figures 2, 3, and 4. Compositional variations in the glasses are greatest in Holes $332 \mathrm{~A}$ and 332B and appear to be independent of either secular or geographic influences.

Glass analyses from Hole 332A fall into three distinct groups (332A-a, -b, and -d); two isolated analyses may represent separate groups (332A-c and -e). Oxide versus $\mathrm{MgO}$ variation suggests a simple two- or three-phase cotectic assemblage relating groups $332 \mathrm{~A}-\mathrm{a}$ and $-\mathrm{b}$, whereas 332A-d, by virtue of higher contents of $\mathrm{TiO}_{2}, \mathrm{~K}_{2} \mathrm{O}, \mathrm{P}_{2} \mathrm{O}_{5}$, and (?) $\mathrm{FeO}$, appears to be unrelated to the other groups (Figure 2).

Five compositional groups are recognized in Hole 332 B (a-e inclusive), notated with increasing depth, and distinguished by relative abundances of $\mathrm{TiO}_{2}, \mathrm{~K}_{2} \mathrm{O}$, $\mathrm{CaO}$, and $\mathrm{Al}_{2} \mathrm{O}_{3}$. Most distinctive are groups 332 $\mathrm{B}-\mathrm{a}$ (high $\mathrm{TiO}_{2}$ and low $\mathrm{Al}_{2} \mathrm{O}_{3}$ ), 332B-b and -c (low $\mathrm{TiO}_{2}$ and high $\mathrm{Al}_{2} \mathrm{O}_{3}$ ), and 332 $\mathrm{B}$-e (high $\mathrm{CaO}$, moderate $\mathrm{Al}_{2} \mathrm{O}_{3}$, and low $\mathrm{TiO}_{2}$ ). None of the groups can be related by simple fractional crystallization schemes involving removal of olivine + plagioclase \pm clinopyroxene. Variations in $\mathrm{TiO}_{2}, \mathrm{Al}_{2} \mathrm{O}_{3}$, and $\mathrm{CaO}$ are compatible with derivation of group $\mathrm{d}$ from group $\mathrm{b}$ by fractional crystallization, but this process is precluded by the higher content of $\mathrm{K}_{2} \mathrm{O}$ in group d glasses. The same argument probably holds for groups $332 \mathrm{~B}-\mathrm{b}$ and -c, which in other respects are nearly identical. The only other possible fractional crystallization sequence is
332B-a toward 332A-d, both high-Ti groups. However, $332 \mathrm{~A}-\mathrm{d}$ is about $0.5 \%$ poorer in $\mathrm{SiO}_{2}$ (Table 1 ) and, being lower in $\mathrm{MgO}$, must derive from a more $\mathrm{SiO}_{2}$-poor parent than 332B-a (Figure 3).

Glasses from Sites 334 and 335 form discrete compositional groups and do not correspond to any from Holes 332A and 332B (Table 1). Site 334 glass compositions are relatively low in $\mathrm{Na}_{2} \mathrm{O}$, moderately high in $\mathrm{CaO}$, and high in $\mathrm{SiO}_{2}$, whereas Site 335 glasses are notable for high $\mathrm{TiO}_{2}$ contents (cf. groups 332A-d and 332B-a, Table 1).

\section{WHOLE-ROCK LITHOLOGY AND CHEMISTRY}

\section{Hole 332A}

\section{Lithology}

Hole $332 \mathrm{~A}$ penetrated 330.5 meters into acoustic basement with about $10 \%$ recovery. Seven lithologic units were recognized by the shipboard party based largely on phenocryst mineralogy. The upper third of the section consists chiefly of aphyric and sparsely phyric basalt with one coarsely plagioclase-phyric unit near the top; moderately to highly plagioclase- and olivine-phyric lavas predominate below about 93 meters subbasement. The hole bottomed in a highly porphyritic basalt containing abundant phenocrysts of plagioclase, augite, and olivine. Chalk layers and glass or palagonite breccias are common in the upper part of the section, but decrease gradually with depth.

The rocks between Cores 30 and 35 (226-283 m subbasement) are notably altered with abundant smectite, carbonate, and zeolite; elsewhere the rocks are relatively fresh, but nearly all exhibit some evidence of interaction with seawater. 
TABLE 2

Average Compositions of Leg 37 Whole-Rock Groups (Volatile-Free), Corrected for Carbonate-Contamination

\begin{tabular}{|c|c|c|c|c|c|c|c|c|c|c|c|c|c|}
\hline & $332 \mathrm{~A}-1$ & $332 \mathrm{~A}-2$ & $332 \mathrm{~A}-3$ & $332 \mathrm{~A}-4$ & $332 \mathrm{~A}-5$ & $332 \mathrm{~A}-6$ & $x$ & $F$ & $332 \mathrm{~B}-1$ & $332 \mathrm{~B}-2$ & $332 \mathrm{~B}-3$ & $332 \mathrm{~B}-4$ & $332 \mathrm{~B}-5$ \\
\hline $\mathrm{SiO}_{2}$ & 49.27 & 51.43 & 50.84 & 50.79 & 49.69 & 50.87 & 49.3 & 50.0 & 48.65 & 50.82 & 48.52 & 48.61 & 49.47 \\
\hline $\mathrm{TiO}_{2}$ & 0.48 & 1.09 & 1.22 & 1.01 & 0.56 & 1.05 & 0.50 & 0.7 & 0.38 & 1.06 & 0.75 & 0.70 & 0.80 \\
\hline $\mathrm{Al}_{2} \mathrm{O}_{3}$ & 20.78 & 14.82 & 14.83 & 16.41 & 16.88 & 15.09 & 17.5 & 17.4 & 21.87 & 15.87 & 14.69 & 14.36 & 16.48 \\
\hline $\mathrm{Fe}_{2} \mathrm{O}_{3}$ & 1.96 & 3.30 & 3.90 & 2.99 & 1.65 & 3.19 & 1.5 & & 1.04 & 2.62 & 2.43 & 2.26 & 2.71 \\
\hline $\mathrm{FeO}$ & 3.93 & 6.69 & 6.73 & 6.00 & 4.98 & 6.37 & 5.75 & 8.2 & 3.92 & 6.24 & 6.72 & 6.67 & 6.25 \\
\hline $\mathrm{MnO}$ & 0.10 & 0.16 & 0.15 & 0.15 & 0.12 & 0.16 & 0.13 & 0.1 & 0.10 & 0.16 & 0.16 & 0.15 & 0.16 \\
\hline $\mathrm{MgO}$ & 6.53 & 7.36 & 7.70 & 7.26 & 10.17 & 7.48 & 9.5 & 9.8 & 7.05 & 7.59 & 13.15 & 14.10 & 9.75 \\
\hline $\mathrm{CaO}$ & 14.90 & 12.50 & 12.08 & 12.97 & 14.22 & 13.14 & 14.2 & 12.9 & 15.40 & 13.16 & 11.36 & 11.10 & 11.88 \\
\hline $\mathrm{Na}_{2} \mathrm{O}$ & 1.77 & 2.18 & 2.10 & 2.05 & 1.57 & 2.22 & 1.55 & 2.2 & 1.51 & 2.12 & 2.01 & 1.88 & 2.30 \\
\hline $\mathrm{K}_{2} \mathrm{O}$ & 0.22 & 0.33 & 0.30 & 0.24 & 0.11 & 0.30 & 0.05 & 0.0 & 0.05 & 0.25 & 0.15 & 0.12 & 0.15 \\
\hline $\mathrm{P}_{2} \mathrm{O}_{5}$ & 0.06 & 0.14 & 0.15 & 0.13 & 0.05 & 0.13 & 0.02 & nd & 0.03 & 0.11 & 0.06 & 0.05 & 0.05 \\
\hline Total & 100.00 & 100.00 & 100.00 & 100.00 & 100.00 & 100.00 & 100.00 & 101.5 & 100.00 & 100.00 & 100.00 & 100.00 & 100.00 \\
\hline $\begin{array}{l}\text { No. of } \\
\text { analyses }\end{array}$ & 2 & 23 & 7 & 15 & 3 & 2 & & & 7 & 12 & 2 & 1 & 4 \\
\hline $\mathrm{Cr}$ & 188 & 99 & 151 & 158 & 411 & 158 & & & 269 & 201 & 760 & 892 & 436 \\
\hline $\mathrm{Ni}$ & 88 & 69 & 84 & 85 & 145 & 78 & & & 103 & 78 & 308 & 372 & 204 \\
\hline $\mathrm{Ba}$ & 29 & 76 & 79 & 68 & 33 & 72 & & & 25 & 76 & 46 & 42 & 43 \\
\hline $\mathrm{Rb}$ & 1.9 & 5.3 & 5.3 & 3.6 & 1.2 & 3.9 & & & 1.3 & 4.3 & 1.7 & 1.7 & 3.1 \\
\hline Sr & 103 & 118 & 112 & 111 & 99 & 105 & & & 112 & 145 & 87 & 86 & 88 \\
\hline Y & 11.5 & 24.7 & 27.0 & 21.9 & 11.6 & 25.4 & & & 10.6 & 23.6 & 18.4 & 18.3 & 20.0 \\
\hline $\mathrm{Zr}_{\mathrm{r}}$ & 37 & 72 & 81 & 67 & 42 & 70 & & & 38 & 68 & 47 & 43 & 46 \\
\hline $\mathrm{Cu}$ & 75 & 75 & 68 & 71 & 75 & 73 & & & 82 & 70 & 85 & 83 & 84 \\
\hline $\mathrm{Zn}$ & 41 & 58 & 58 & 54 & 43 & 56 & & & & & & & \\
\hline $\mathrm{CaO} / \mathrm{Al}_{2} \mathrm{O}_{3}$ & 0.717 & 0.843 & 0.815 & 0.790 & 0.842 & 0.871 & 0.811 & 0.741 & 0.704 & 0.829 & 0.773 & 0.773 & 0.721 \\
\hline $\mathrm{P} / \mathrm{Y}$ & 22.8 & 24.7 & 24.2 & 25.9 & 18.8 & 22.4 & & & 12.4 & 20.4 & 14.2 & 11.9 & 13.1 \\
\hline $\mathrm{Zr} / \mathrm{Y}$ & 3.21 & 2.91 & 3.00 & 3.05 & 3.62 & 2.75 & & & 3.58 & 2.88 & 2.55 & 2.35 & 2.30 \\
\hline $\begin{array}{l}100 \times \mathrm{Mg} / \\
\left(\mathrm{Kg}+\mathrm{Fe}^{+2}\right)\end{array}$ & & & & & & & 74.6 & 71.6 & & & & & \\
\hline
\end{tabular}

\section{Major Element Geochemistry}

Six magma groups are recognized in Hole 332A (1-6 inclusive), generally notated with increasing depth (Figure 2 and Table 2).

Group 332A-1-Group 1 comprises about 10 meters of highly plagioclase-phyric basalt (lithologic unit 2) lying immediately beneath a thin aphyric sequence at the sediment-basalt contact. It is characterized by exceptionally high $\mathrm{Al}_{2} \mathrm{O}_{3}$ (up to $21 \mathrm{wt} \%$ ) and $\mathrm{CaO}$ (15 wt \%) and low $\mathrm{TiO}_{2}$, total iron, $\mathrm{SiO}_{2}$, and $\mathrm{P}_{2} \mathrm{O}_{5}$. The porphyritic rocks are divided by a thin aphyric layer (belonging to magma group 332A-6), but there are no glassy zones or sedimentary intercalations.

Large plagioclase phenocrysts (up to 20 modal percent) are relatively uniform in composition (An $n_{92}$, but many have narrow overgrowths of more sodic composition. Microphenocrysts of plagioclase are slightly more sodic with an average composition of $A n_{88}$. Olivine microphenocrysts (1 modal percent) have an average composition of Foss.

Chemical variations within this group (Figure 2) suggest that it originated by addition of An-rich plagioclase to a magma already poor in $\mathrm{TiO}_{2}, \mathrm{~K}_{2} \mathrm{O}$, and $\mathrm{P}_{2} \mathrm{O}_{5}$, and rich in $\mathrm{CaO}$ and $\mathrm{Al}_{2} \mathrm{O}_{3}$.

Group 332A-2-This is the most voluminous magma type in Hole 332A, and it encompasses a range of compositions between glass groups 332A-a and - b, including a few compositions more magnesian than 332A-a (Figure 2). It comprises most of lithologic units 3 and 4 , a sequence of sparsely phyric and aphyric basalts, respectively. Where present, phenocrysts are of plagioclase (An84), clinopyroxene, and olivine (Fo85). Variation of $\mathrm{TiO}_{2}, \mathrm{CaO}$, and $\mathrm{Al}_{2} \mathrm{O}_{3}$ indicates simple cotectic fractionation of the phenocryst phases and probably reflects a series of closely related fractionation paths rather than a single liquid line.

Group 332A-3-This group has higher $\mathrm{TiO}_{2}(1.2 \mathrm{wt}$ $\%$ ) and $\mathrm{P}_{2} \mathrm{O}_{5}$ than $332 \mathrm{~A}-2$ for equivalent $100 \times$ $\mathrm{Mg} /\left(\mathrm{Mg}+\mathrm{Fe}^{+2}\right)$ and is closely related chemically and stratigraphically to $332 \mathrm{~A}-\mathrm{d}$ glass compositions (Figure 2). Lavas of this group make up lithologic unit 5 and include a few intercalated layers at the base of lithologic unit 6 . They are sparsely phyric, with small phenocrysts of plagioclase (An85-88), clinopyroxene, and olivine (Fos3). Group 332A-3 compositions are mostly intermediate between 332A-d and 332B-a glass compositions. However, as already indicated, any magma associated with the $332 \mathrm{~A}-\mathrm{d}$ glasses must have been derived from a less $\mathrm{SiO}_{2}$-rich magma than that giving rise to 332B-a glass compositions (cf. Figures 2 and 3).

Group 332A-4-Basalts of this group form lithologic unit 6 , a series of coarsely plagioclase-phyric lavas, intercalated near the base with rocks of group $332 \mathrm{~A}-3$ (Figure 5). Oxide variation (Figure 2) indicates plagioclase accumulation in a range of host liquids more magnesian than, and probably parental to, group 332A-3 magmas. $\mathrm{Al}_{2} \mathrm{O}_{3}$ and $\mathrm{CaO}$ contents are high (up to 16.8 and 13.8 wt \%, respectively), but plots of $\mathrm{SiO}_{2}$ and $\mathrm{CaO}$ versus $\mathrm{MgO}$ suggest variability in the composition of the added plagioclase (An85-88). 
TABLE 2 - Continued

\begin{tabular}{|c|c|c|c|c|c|c|c|c|c|c|c|c|c|}
\hline & $332 \mathrm{~B}-6 \mathrm{~A}$ & $332 \mathrm{~B}-6 \mathrm{~B}$ & $332 \mathrm{~B}-7$ & $333 \mathrm{~A}-1$ & $333 \mathrm{~A}-2$ & $333 \mathrm{~A}-3$ & $333 \mathrm{~A} 4$ & $333 A-5$ & $334-1$ & $334-2$ & $334-3$ & $334-4$ & $335-1$ \\
\hline $\mathrm{SiO}_{2}$ & 47.70 & 48.78 & 50.37 & 51.08 & 51.34 & 51.00 & 49.96 & 51.20 & 51.67 & 51.44 & 49.94 & 44.82 & 50.28 \\
\hline $\mathrm{TiO}_{2}^{2}$ & 0.56 & 0.52 & 1.02 & 0.96 & 1.05 & 1.44 & 0.70 & 1.16 & 0.89 & 0.77 & 0.13 & 0.07 & 1.11 \\
\hline $\mathrm{Al}_{2} \mathrm{O}_{3}$ & 13.76 & 19.11 & 16.04 & 14.80 & 15.03 & 15.48 & 16.47 & 15.90 & 15.80 & 15.17 & 16.84 & 5.47 & 15.72 \\
\hline $\mathrm{Fe}_{2} \mathrm{O}_{3}$ & 2.75 & 2.37 & 2.79 & 2.22 & 3.93 & 3.50 & 2.23 & 2.19 & 1.29 & 2.69 & 1.96 & 3.89 & 3.97 \\
\hline $\mathrm{FeO}$ & 6.45 & 4.23 & 6.33 & 5.91 & 5.69 & 6.16 & 5.03 & 6.82 & 7.52 & 5.67 & 4.86 & 5.21 & 5.48 \\
\hline $\mathrm{MnO}$ & 0.16 & 0.14 & 0.18 & 0.16 & 0.17 & 0.15 & 0.15 & 0.16 & 0.16 & 0.16 & 0.15 & 0.10 & 0.16 \\
\hline $\mathrm{MgO}$ & 16.15 & 8.23 & 7.96 & 10.24 & 8.30 & 7.73 & 8.61 & 7.90 & 8.05 & 8.94 & 10.87 & 36.01 & 8.45 \\
\hline $\mathrm{CaO}$ & 10.50 & 14.68 & 12.73 & 12.52 & 11.80 & 11.79 & 14.89 & 12.31 & 12.29 & 13.12 & 14.16 & 4.27 & 11.98 \\
\hline $\mathrm{Na}_{2} \mathrm{O}$ & 1.78 & 1.79 & 2.23 & 1.94 & 2.39 & 2.34 & 1.78 & 2.13 & 2.04 & 1.86 & 1.07 & 0.15 & 2.46 \\
\hline $\mathrm{K}_{2} \mathrm{O}$ & 0.15 & 0.11 & 0.25 & 0.17 & 0.19 & 0.27 & 0.13 & 0.13 & 0.21 & 0.12 & 0.02 & 0.01 & 0.28 \\
\hline $\mathrm{P}_{2} \mathrm{O}_{5}$ & 0.04 & 0.04 & 0.10 & - & 0.11 & 0.14 & 0.05 & 0.10 & 0.08 & 0.06 & - & - & 0.11 \\
\hline Total & 100.00 & 100.00 & 100.00 & 100.00 & 100.00 & 100.00 & 100.00 & 100.00 & 100.00 & 100.00 & 100.00 & 100.00 & 100.00 \\
\hline $\begin{array}{l}\text { No. of } \\
\text { analyses }\end{array}$ & 6 & 4 & 13 & 2 & 2 & 3 & 3 & 3 & 1 & 3 & 2 & 2 & 7 \\
\hline $\mathrm{Cr}$ & 1300 & 434 & 181 & 681 & 158 & 281 & 466 & 276 & 249 & 168 & 732 & 5477 & 256 \\
\hline $\mathrm{Ni}$ & 499 & 131 & 84 & 225 & - & 94 & 119 & 102 & 114 & 100 & 225 & 2170 & 154 \\
\hline $\mathrm{Ba}$ & 32 & 29 & 69 & 79 & 91 & 111 & 57 & 80 & 84 & 66 & 18 & 6.2 & 63 \\
\hline $\mathrm{Rb}$ & 3.9 & 1.8 & 3.5 & 2.3 & 2.7 & 7.2 & 2.4 & 2.4 & 2.7 & 2.4 & 0.3 & - & 4.3 \\
\hline $\mathrm{Sr}$ & 93 & 109 & 112 & 136 & 107 & 122 & 147 & 115 & 87 & 75 & 30 & 2.7 & 106 \\
\hline $\mathrm{Y}$ & 15.7 & 15.8 & 23.9 & 20.7 & 24.6 & 29.1 & 18.0 & 25.0 & 22.7 & 20.4 & 5.3 & 2.6 & 26.2 \\
\hline $\mathrm{Zr}_{\mathrm{r}}$ & 36 & 39 & 63 & 71 & 76 & 90 & 54 & 74 & 49 & 41 & 6.9 & 4.9 & 56 \\
\hline $\mathrm{Cu}$ & 90 & 85 & 62 & 77 & 80 & 56 & 62 & 71 & 64 & 96 & 90 & 34 & 68 \\
\hline $\mathrm{Zn}$ & & & & & & & & & nd & nd & nd & nd & 54 \\
\hline $\mathrm{CaO} / \mathrm{Al}_{2} \mathrm{O}_{3}$ & 0.763 & 0.768 & 0.794 & 0.846 & 0.785 & 0.762 & 0.904 & 0.774 & 0.778 & 0.865 & 0.841 & 0.781 & 0.762 \\
\hline $\mathrm{P} / \mathrm{Y}$ & 11.1 & 11.1 & 18.3 & - & 19.6 & 21.0 & 12.1 & 17.5 & 15.4 & 12.8 & - & - & 16.7 \\
\hline $\mathrm{Zr} / \mathrm{Y}$ & 2.29 & 2.47 & 2.64 & 3.43 & 3.09 & 3.09 & 3.00 & 2.96 & 2.16 & 2.01 & 1.30 & 1.88 & 2.14 \\
\hline
\end{tabular}

${ }^{\mathrm{a}} X=$ calculated noncumulate host composition for 332B-1.

${ }^{b_{F}}=$ Glass composition 3-14 from Frey et al. (1974).

Group 332A-5-The rock type comprising this magma group is unique among Leg 37 basalts. It is highly porphyritic, with phenocrysts of clinopyroxene, plagioclase $\left(\mathrm{An}_{88-89}\right)$, olivine (Fo89), and minor spinel, and is probably the result of crystal accumulation. It forms the lowermost drilled unit (lithologic unit 7) in Hole $332 \mathrm{~A}$ and is chemically distinctive, with $\mathrm{MgO}$ ranging from 9.5 to 11 wt $\%$ and $\mathrm{CaO}$ and $\mathrm{Al}_{2} \mathrm{O}_{3}$ commonly exceeding 14 and 16.5 wt \%, respectively. Extrapolation from the bulk composition by removal of cumulate phases suggests that the host liquid was rich in $\mathrm{CaO}$ and $\mathrm{Al}_{2} \mathrm{O}_{3}$ and poor in $\mathrm{TiO}_{2}, \mathrm{~K}_{2} \mathrm{O}$, and $\mathrm{P}_{2} \mathrm{O}_{5}$, similar in composition to that predicted for plagioclase cumulate magmas of groups $332 \mathrm{~A}-1$ and $332 \mathrm{~B}-1$.

Group 332A-6-Two specimens (Core 7, Section 1, 20-22 cm; and Core 21, Section 1, 31-33 cm), although chemically similar to magmas of group 332A-2, are assigned to a separate group because of their distinctly higher $\mathrm{Cr}$ contents and $100 \times \mathrm{Cr} /(\mathrm{Cr}+\mathrm{Ni})$ ratios (Table 2).

\section{Trace and Minor Element Geochemistry}

In Figure $6, \mathrm{Ti}, \mathrm{Sr}$, and $\mathrm{Y}$ contents of $332 \mathrm{~A}$ basalts are plotted against $\mathrm{Zr}$. $\mathrm{Zr}$ is used as the abscissa because of its "incompatible" character and its low mobility during post-crystallization alteration processes (Cann, 1970; Pearce and Cann, 1971). Lines of equal element/Zr ratio have been drawn to monitor any departure from unity in the rocks. Such differences should reflect magmatic source processes if they cannot be attributed to fractional crystallization or alteration. Effects of low pressure fractional crystallization should reflect the observed effects on interelement ratios of phenocryst-phase cumulates.

Good correlation between $\mathrm{Ti}$ and $\mathrm{Zr}$ is observed for all magma groups, cumulate and noncumulate, with $\mathrm{Ti} / \mathrm{Zr}$ ratios of 80 to 90 . Sr has a high partition coefficient between plagioclase and basaltic matrix $(D=$ 1-3; Philpotts and Schnetzler, 1970), clearly evidenced by the high $\mathrm{Sr} / \mathrm{Zr}$ ratios of plagioclase cumulates in groups $332 \mathrm{~A}-1,-4$, and -5 (Figure 6).

The $\mathrm{Zr} / \mathrm{Y}$ ratio appears to be unaffected by plagioclase accumulation; however, there is a perceptible difference in $\mathrm{Zr} / \mathrm{Y}$ between noncumulate magmas $332 \mathrm{~A}-2$ and -3 (Table 2). The ratio of $\mathrm{P} / \mathrm{Y}$ is likewise unaffected by accumulation (or fractionation) of plagioclase (cf. 332A-4 and -3 , Table 2), and probably olivine and clinopyroxene. $\mathrm{P} / \mathrm{Y}$ and $\mathrm{Zr} / \mathrm{Y}$ ratios are probably inherent features of mantle-derived liquids, unless garnet has been fractionated at high pressure. Average values of $\mathrm{P} / \mathrm{Y}$ are similar for all magma groups, ranging from 22 to 26 , except for group 332A-5 (18.8).

$\mathrm{Ba}$ and $\mathrm{Rb}$ are enriched with $\mathrm{Zr}$ although considerable scatter is introduced by alteration effects (cf. Ridley et al., 1974).

$\mathrm{Cr}$ abundance and the ratio $100 \times \mathrm{Cr} /(\mathrm{Cr}+\mathrm{Ni})$ are diagnostic for each group. $\mathrm{Cr}$ contents are similar (150 to $170 \mathrm{ppm}$ ) in groups $332 \mathrm{~A}-3,-4$, and -6 , all of which have $\mathrm{MgO}$ in the range of 6.5 to $8.0 \mathrm{wt} \%$. Cr is distinct- 
TABLE 3A

Average Plagioclase Compositions of the Magma Groups, Hole 332A

\begin{tabular}{lcrrrrrrrrrr}
\hline & 1 & \multicolumn{1}{c}{2} & \multicolumn{1}{c}{3} & \multicolumn{1}{c}{4} & \multicolumn{1}{c}{5} & \multicolumn{1}{c}{6} & 7 & \multicolumn{1}{c}{8} & 9 & 10 & 11 \\
\hline $\mathrm{SiO}_{2}$ & 44.71 & 46.21 & 47.71 & 47.27 & 49.82 & 46.05 & 46.60 & 50.47 & 45.36 & 45.80 & 46.56 \\
$\mathrm{Al}_{2} \mathrm{O}_{3}$ & 35.44 & 34.33 & 32.63 & 33.57 & 31.21 & 34.42 & 33.99 & 30.38 & 35.30 & 35.02 & 33.89 \\
$\mathrm{CaO}$ & 19.43 & 18.99 & 16.92 & 17.87 & 15.33 & 18.37 & 18.06 & 15.00 & 18.35 & 17.80 & 17.69 \\
$\mathrm{Na}_{2} \mathrm{O}$ & 0.99 & 1.50 & 2.27 & 1.88 & 2.98 & 1.44 & 1.71 & 3.19 & 1.31 & 1.37 & 1.60 \\
$\mathrm{~K}_{2} \mathrm{O}$ & 0.00 & 0.00 & 0.02 & 0.01 & 0.05 & \multicolumn{1}{c}{$\mathrm{tr}$} & 0.01 & 0.08 & 0.00 & 0.00 & 0.01 \\
$\mathrm{FeO}^{\mathrm{a}}$ & 0.22 & 0.27 & 0.60 & 0.39 & 0.63 & 0.35 & 0.36 & 0.76 & 0.37 & 0.36 & 0.53 \\
$\mathrm{MgO}^{\mathrm{O} O}$ & 0.28 & 0.30 & 0.39 & 0.24 & 0.45 & 0.21 & 0.22 & 0.39 & 0.20 & 0.23 & 0.24 \\
$\mathrm{TiO}$ & 0.00 & 0.00 & 0.02 & 0.02 & 0.05 & 0.00 & 0.03 & 0.05 & 0.03 & 0.02 & 0.03 \\
$\mathrm{Total}$ & 101.07 & 101.60 & 100.56 & 101.25 & 100.52 & 100.84 & 100.98 & 100.32 & 100.92 & 100.60 & 100.55 \\
$\mathrm{An}$ & 91.6 & 87.6 & 80.5 & 83.9 & 73.7 & 87.6 & 85.3 & 71.9 & 88.6 & 87.8 & 85.9 \\
\hline
\end{tabular}

Note: 1, Large phenocryst - magma group $1 ; 2$, Small phenocryst - magma group $1 ; 3$, Groundmass microlites magma group $1 ; 4$, Small phenocryst - magma group 2;5, Groundmass lath - magma group 2;6, Large phenocrysts - magma group 4 ( 7 crystals); 7, Microphenocrysts - magma group 4 (6 crystals); 8, Groundmass microlites magma group 4 (5 crystals); 9 , Large phenocryst - magma group $6 ; 10$, Small phenocryst - magma group $6 ; 11$, Groundmass microlite - magma group 6.

${ }^{\mathrm{a}}$ Total Iron.

TABLE 3B

Average Plagioclase Compositions of the Magma Groups, Hole 332B

\begin{tabular}{lrrrrr}
\hline & 1 & 2 & 3 & 4 & 5 \\
\hline $\mathrm{SiO}_{2}$ & 45.46 & 50.03 & 45.66 & 46.60 & 50.67 \\
$\mathrm{Al}_{2} \mathrm{O}_{3}$ & 34.86 & 31.63 & 34.71 & 34.14 & 30.70 \\
$\mathrm{CaO}$ & 18.55 & 15.10 & 18.79 & 17.83 & 14.80 \\
$\mathrm{Na}_{2} \mathrm{O}$ & 1.20 & 2.92 & 1.29 & 1.79 & 3.22 \\
$\mathrm{~K}_{2} \mathrm{O}$ & 0.00 & 0.04 & 0.01 & 0.02 & 0.03 \\
$\mathrm{FeO}^{\mathrm{a}}$ & 0.27 & 0.72 & 0.33 & 0.38 & 0.70 \\
$\mathrm{MgO}^{\mathrm{O} O}$ & 0.23 & 0.36 & 0.18 & 0.22 & 0.29 \\
$\mathrm{TiO}_{2}$ & 0.03 & 0.03 & tr & 0.01 & 0.05 \\
$\mathrm{Total}$ & 100.60 & 100.83 & 100.95 & 100.99 & 100.46 \\
$\mathrm{An}$ & 89.5 & 74.9 & 89.0 & 84.5 & 71.5 \\
\hline
\end{tabular}

Note: 1 , Large phenocryst - magma group $1 ; 2$, Groundmass microlites - magma group 1 ( 2 crystals); 3, Large phenocrysts - magma group 2 ( 3 crystals); 4, Small phenocrysts - magma group 2 ( 3 crystals); 5 , Groundmass microlites - magma group 2 ( 3 crystals).

${ }^{\mathrm{a}}$ Total iron.

ly lower in group 332A-2 magmas ( $85-110 \mathrm{ppm}$ ). Group 332A-3 and - 4 magmas are also characterized by higher $\mathrm{Ti}$ and $\mathrm{Zr}$ contents than groups 332A-2 and -6 magmas for equivalent $\mathrm{MgO}$ contents.

\section{Geochemical Stratigraphy}

The magma groups in Hole $332 \mathrm{~A}$ have a simple stratigraphic sequence and chemical variation with depth shows good correspondence with lithologic variation (Figure 5).

The highly porphyritic basalt (group $332 \mathrm{~A}-5$ ) at the base of the section probably represents the residual cumulate of a fractionated body of $\mathrm{CaO}-$ and $\mathrm{Al}_{2} \mathrm{O}_{3}-$ rich magma. The succeeding highly phyric and sparsely phyric magmas of groups $332 \mathrm{~A}-4$ and $332 \mathrm{~A}-3$, respectively, probably reflect a complex magma fractionation system. The thick $(160 \mathrm{~m})$ sequence of group 332A-2 magmas that followed, reflects repeated episodes of fractionation, eruption, and replenishment within highlevel sub-rift magma chambers. Rare intercalations of group 332A-6 magma in lithologic units 4 and 2 appear to derive from an independent system, as does the uppermost plagioclase phyric basalt (group 332A-1).

Paleomagnetic stratigraphy (Hall and Ryall, Chapter 16, this volume) suggests eruptive episodes may be about $100 \mathrm{yr}$ in duration with long intervening quiescent periods. Thus, if buildup of the drilled section occurred over about $100,000 \mathrm{yr}$ (a plausible estimate considering crustal spreading rates and width of the active median rift), complex patterns of magma fractionation are to be expected.

Cyclic variation of $100 \times \mathrm{Mg} /\left(\mathrm{Mg}+\mathrm{Fe}^{+2}\right), \mathrm{Cr}, \mathrm{Ni}$, and LIL-elements with depth is observed within lavas belonging to magma groups $332 \mathrm{~A}-2,-3$, and -4 (Figure 7). Typical cycles begin with eruption of $\mathrm{MgO}$-poor,

TABLE 3C

Average Plagioclase Compositions of the Magma Groups, Sites 333 and 335

\begin{tabular}{lrcrcr}
\hline & 1 & 2 & 3 & 4 & \multicolumn{1}{c}{5} \\
\hline $\mathrm{SiO}_{2}$ & 46.30 & 46.30 & 49.98 & 45.97 & 50.06 \\
$\mathrm{Al}_{2} \mathrm{O}_{3}$ & 34.75 & 34.58 & 31.79 & 34.92 & 31.52 \\
$\mathrm{CaO}$ & 18.32 & 18.57 & 15.55 & 18.32 & 15.78 \\
$\mathrm{Na}{ }_{2} \mathrm{O}$ & 1.49 & 1.45 & 2.87 & 1.47 & 2.09 \\
$\mathrm{~K}_{2} \mathrm{O}$ & 0.01 & tr & 0.03 & tr & 0.03 \\
$\mathrm{FeO}^{\mathrm{a}}$ & 0.31 & 0.32 & 0.60 & 0.41 & 0.52 \\
$\mathrm{MgO}_{\mathrm{T} O}$ & 0.25 & 0.23 & 0.29 & 0.21 & 0.32 \\
$\mathrm{TiO}_{2}$ & 0.00 & 0.00 & 0.03 & 0.00 & 0.05 \\
Total & 101.44 & 101.45 & 101.14 & 101.30 & 100.85 \\
An & 87.2 & 87.5 & 74.9 & 87.4 & 80.5 \\
\hline
\end{tabular}

Note: 1, Hole 333A; small phenocryst - magma group 2; 2 , Hole $333 \mathrm{~A}$; small phenocrysts - magma group 3 ( 3 crystals); 3 , Hole 333A; groundmass microlite - magma group $3 ; 4$, Site 335 ; small phenocrysts - magma group 1 ( 2 crystals); 5 , Site 335 ; groundmass microlite - magma group 1 .

${ }^{\text {a }}$ Total iron. 
TABLE 4A

Average Olivine Compositions of the Magma Groups, Hole 332A

\begin{tabular}{lrrrrrrr}
\hline & 1 & 2 & 3 & 4 & 5 & 6 & 7 \\
\hline $\mathrm{SiO}_{2}$ & 40.29 & 39.73 & 39.38 & 39.38 & 39.38 & 40.10 & 39.76 \\
$\mathrm{MgO}$ & 47.95 & 45.57 & 44.36 & 44.88 & 44.63 & 47.80 & 46.91 \\
$\mathrm{FeO}$ & 11.06 & 14.58 & 16.51 & 14.82 & 14.82 & 10.88 & 12.39 \\
$\mathrm{MnO}$ & 0.18 & 0.20 & 0.23 & 0.22 & 0.23 & 0.16 & 0.19 \\
$\mathrm{CaO}$ & 0.41 & 0.37 & 0.35 & 0.33 & 0.32 & 0.31 & 0.33 \\
$\mathrm{TiO}_{2}$ & 0.00 & 0.00 & 0.02 & \multicolumn{1}{c}{ tr } & 0.01 & 0.00 & 0.00 \\
$\mathrm{NiO}_{\mathrm{Cr}} \mathrm{O}_{3}$ & 0.19 & 0.11 & 0.15 & 0.15 & 0.15 & 0.21 & 0.14 \\
$\mathrm{Total}$ & 0.05 & 0.00 & 0.00 & 0.03 & 0.03 & 0.04 & 0.01 \\
$\mathrm{Fo}$ & 88.5 & 84.7 & 92.7 & 84.4 & 84.3 & 88.7 & 87.1 \\
\hline
\end{tabular}

Note: 1 , Phenocrysts - magma group 1 ( 2 crystals); 2 , Microphenocryst magma group 2; 3 , Microphenocrysts - magma group 3 ( 2 crystals); 4 , Phenocrysts - magma group 4 (4 crystals); 5, Groundmass crystals magma group 4 (4 crystals); 6, Phenocryst - magma group $6 ; 7$, microphenocrysts - magma group 6 .

${ }^{\mathrm{a}}$ Total iron.

TABLE 4B

Average Olivine Compositions of the Magma Groups, Hole 332B

\begin{tabular}{lccc}
\hline & 1 & 2 & \multicolumn{1}{c}{3} \\
\hline $\mathrm{SiO}_{2}$ & 39.80 & 39.96 & 40.72 \\
$\mathrm{MgO}$ & 48.26 & 48.35 & 47.26 \\
$\mathrm{FeO}^{\mathrm{a}}$ & 10.64 & 10.61 & 11.08 \\
$\mathrm{MnO}$ & 0.16 & 0.17 & 0.16 \\
$\mathrm{CaO}$ & 0.37 & 0.37 & 0.34 \\
$\mathrm{TiO}_{2}$ & 0.00 & 0.00 & 0.01 \\
$\mathrm{NiO}_{\mathrm{O}}$ & 0.18 & 0.18 & 0.26 \\
$\mathrm{Cr}_{2} \mathrm{O}_{3}$ & 0.05 & 0.06 & 0.06 \\
$\mathrm{Total}$ & 99.46 & 99.70 & 99.89 \\
Fo & 89.0 & 89.6 & 88.4 \\
\hline
\end{tabular}

Note: 1 , Phenocrysts - magma group 1 ( 2 crystals); 2 , Microphenocrysts - magma group 1 (2 crystals); 3, Microphenocrysts - magma group 6 ( 3 crystals).

${ }^{\mathrm{a}}$ Total iron.

TABLE 4C

Average Olivine Compositions of the Magma Groups, Sites 333 and 335

\begin{tabular}{lrrrr}
\hline & 1 & 2 & \multicolumn{1}{c}{3} & \multicolumn{1}{c}{4} \\
\hline $\mathrm{SiO}_{2}$ & 39.89 & 39.18 & 39.07 & 39.86 \\
$\mathrm{MgO}$ & 46.08 & 44.28 & 43.84 & 48.65 \\
$\mathrm{FeO}^{\mathrm{a}}$ & 13.53 & 15.67 & 15.88 & 10.91 \\
$\mathrm{MnO}$ & 0.20 & 0.25 & 0.22 & 0.15 \\
$\mathrm{CaO}$ & 0.33 & 0.32 & 0.29 & 0.30 \\
$\mathrm{NiO}$ & 0.15 & 0.10 & 0.11 & 0.21 \\
$\mathrm{Cr}_{2} \mathrm{O}_{3}$ & 0.00 & 0.00 & 0.00 & 0.05 \\
$\mathrm{Total}$ & 100.18 & 99.80 & 99.40 & 100.14 \\
Fo & 85.9 & 83.4 & 83.1 & 88.8 \\
\hline
\end{tabular}

Note: 1, Hole 333A; phenocryst - magma group 1; 2, Hole 333A; microphenocryst magma group $1 ; 3$, Hole $333 \mathrm{~A}$; microphenocryst - magma group $2 ; 4$, Site 335 ; phenocrysts - magma group 1 ( 3 crystals).

${ }^{\mathrm{a}}$ Total iron. often plagioclase cumulative lavas, followed by more mafic types, and reflect the episodic construction of layer 2.

The succession of group 332A-4 and 332A-3 magmas may reflect a larger scale cyclic unit, possibly relating to a deep-seated fractionation event of more primitive magma, on which smaller scale effects have been superimposed at high levels. Tectonically quiet periods are probably shorter and hence opportunities for crystal-liquid fractionation are less in high-level sub-rift regions than at greater depths. Intercalation of group 332A-3 lavas in group 4 lavas reflects availability of both types over a considerable period of time, although group 3 magmas continued erupting long after cessation of group 4 eruptions. It is conceivable that other highly phyric, cumulate magmas (e.g., groups 332A-1 and 332A-5) may also represent extreme fractions of large cyclic processes.

The thickest paleomagnetic units, M8 and M7 (Figure 7) correspond to the most massive eruptive sequence including magmas of group $332 \mathrm{~A}-5,332 \mathrm{~A}-4$, and $332 \mathrm{~A}-3$. The base of magnetic unit M6 (at about $280 \mathrm{~m}$ depth) coincides with the cessation of group 332A-3 magmas, and the first appearance of the distinctive $332 \mathrm{~A}-2$ group. This is probably the most important chemical break in the section at Hole 332A. The first appearance of group 332A-6 magma corresponds with paleomagnetic unit M5, whereas later units coincide with more pronounced cyclic variations. Sedimentary intercalations become more frequent at and above the chemical transition in magnetic unit M6.

\section{Hole 332B}

\section{Lithology}

In Hole 332B, 583 meters of basement were drilled with an average recovery of $21 \%$. Eleven major lithologic units were defined by the shipboard party using the same criteria as for Hole $332 \mathrm{~A}$. These units consist of either a relatively uniform lithologic sequence or a sequence of repetitive lithologies such as Units 6 and 
TABLE 5A

Average Clinopyroxene Compositions of the Magma Groups, Hole 332A

\begin{tabular}{lcrrrrrrr}
\hline & 1 & \multicolumn{1}{c}{2} & \multicolumn{1}{c}{3} & \multicolumn{1}{c}{4} & \multicolumn{1}{c}{5} & \multicolumn{1}{c}{6} & \multicolumn{1}{c}{7} & \multicolumn{1}{c}{8} \\
\hline $\mathrm{SiO}_{2}$ & 53.63 & 53.16 & 53.59 & 53.19 & 51.60 & 51.84 & 53.85 & 53.45 \\
$\mathrm{Al}_{2} \mathrm{O}_{3}$ & 1.80 & 2.06 & 1.77 & 2.31 & 3.38 & 3.06 & 2.51 & 2.51 \\
$\mathrm{FeO}^{\mathrm{a}}$ & 5.30 & 5.13 & 6.96 & 6.04 & 7.54 & 7.44 & 3.88 & 4.04 \\
$\mathrm{MnO}$ & 0.15 & 0.14 & 0.20 & 0.16 & 0.19 & 0.19 & 0.11 & 0.10 \\
$\mathrm{MgO}$ & 18.08 & 17.98 & 19.49 & 18.09 & 17.54 & 16.66 & 17.49 & 17.89 \\
$\mathrm{CaO}$ & 20.91 & 20.86 & 17.72 & 19.59 & 18.45 & 19.51 & 21.57 & 21.33 \\
$\mathrm{Na}_{2} \mathrm{O}$ & 0.17 & 0.18 & 0.12 & 0.18 & 0.20 & 0.20 & 0.18 & 0.17 \\
$\mathrm{TiO}_{2}$ & 0.28 & 0.30 & 0.29 & 0.39 & 0.68 & 0.68 & 0.21 & 0.19 \\
$\mathrm{NiO}$ & tr & 0.02 & 0.03 & 0.02 & 0.04 & 0.01 & 0.05 & 0.03 \\
$\mathrm{Cr}_{2} \mathrm{O}_{3}$ & 0.10 & 0.21 & 0.09 & 0.62 & 0.31 & 0.17 & 0.61 & 0.43 \\
$\mathrm{Total}^{10}$ & 10.42 & 100.04 & 100.26 & 100.60 & 99.94 & 99.76 & 100.46 & 100.14 \\
$\mathrm{En}$ & 50.1 & 50.1 & 53.9 & 50.9 & 50.1 & 47.8 & 49.7 & 50.4 \\
\hline
\end{tabular}

Note: 1 , Phenocrysts - magma group 2 (4 crystals); 2 , Microphenocrysts - magma group 2 (6 crystals); 3, Groundmass microlite - magma group 2; 4, Microphenocryst magma group $3 ; 5$, Groundmass microlite - magma group $3 ; 6$, Groundmass microlites - magma group 4 ( 3 crystals); 7, Microphenocryst - magma group 6; 8, Phenocrysts - magma group 6 ( 2 crystals).

${ }^{\mathrm{a}}$ Total iron.

TABLE 5B

Average Clinopy roxene Compositions of the Magma Groups, Hole 332B

\begin{tabular}{|c|c|c|c|}
\hline & 1 & 2 & 3 \\
\hline $\mathrm{SiO}_{2}$ & 51.08 & 51.49 & 51.38 \\
\hline $\mathrm{Al}_{2} \mathrm{O}_{3}$ & 3.84 & 2.98 & 4.10 \\
\hline $\mathrm{FeO}^{\mathrm{a}}$ & 7.75 & 7.85 & 7.75 \\
\hline $\mathrm{MnO}$ & 0.20 & 0.20 & 0.18 \\
\hline $\mathrm{MgO}$ & 16.22 & 16.30 & 13.83 \\
\hline $\mathrm{CaO}$ & 19.15 & 19.57 & 20.75 \\
\hline $\mathrm{Na}_{2} \mathrm{O}$ & 0.19 & 0.19 & 0.26 \\
\hline $\mathrm{TiO}_{2}$ & 0.58 & 0.79 & 0.71 \\
\hline $\mathrm{NiO}$ & 0.00 & 0.00 & 0.00 \\
\hline $\mathrm{Cr}_{2} \mathrm{O}_{3}$ & 0.21 & 0.17 & 0.26 \\
\hline Total & 99.22 & 99.54 & 99.23 \\
\hline En & 47.3 & 46.9 & 41.8 \\
\hline
\end{tabular}

Note: 1, Groundmass microlites magma group 1 (2 crystals); 2 , Groundmass microlites - magma group 2 (5 crystals); 3, Groundmass microlite - magma group 6 .

${ }^{\mathrm{a}}$ Total iron.

9. Rhythmic lithologic variations are most common in the lower parts of the section.

Most of the basalts encountered in this hole are moderately to highly phyric with phenocrysts of plagioclase, olivine, and, less commonly, augite. Aphyric and sparsely phyric units are restricted to the upper and lower parts of the section. The presence of aphanitic or intersertal groundmass textures in most rocks and the occurrence and distribution of vesicles and glass rinds suggest that most of the succession consists of pillow basalts. Possible intrusive bodies are present in Cores 9, 10,11, and 26. These are recognized by the absence of strong vesiculation and the presence of coarser grained, microdiabasic textures. These units typically consist of several meters of uniformly textured core bounded above and below by chilled zones.

Altered and brecciated material is more abundant in Hole 332B than in 332A. The most intense alteration occurs in a 100-meter-thick interval (Cores 40-47, inclusive) characterized by abundant secondary carbonate.

\section{Major Element Geochemistry}

Seven magma groups have been defined from oxide versus $\mathrm{MgO}$ variation diagrams (Table 2 and Figure 3 ).

Group 332B-1-Group 332B-1 comprises a 70meter-thick series of coarsely plagioclase-phyric rocks at the top of the section superficially resembling group $332 \mathrm{~A}-1$ rocks. They are, however, even more highly

TABLE 5C

Average Clinopyroxene Compositions of the Magma Groups, Sites 333 and 335

\begin{tabular}{lrrrrrr}
\hline \multicolumn{7}{c}{ Magma Groups, } \\
\hline \multicolumn{1}{c}{1} & \multicolumn{1}{c}{2} & \multicolumn{1}{c}{3} & 4 & \multicolumn{1}{c}{5} & \multicolumn{1}{c}{6} \\
\hline $\mathrm{SiO}_{2}$ & 53.01 & 52.27 & 53.02 & 52.34 & 52.89 & 49.09 \\
$\mathrm{Al}_{2} \mathrm{O}_{3}$ & 2.16 & 2.91 & 2.95 & 3.43 & 3.08 & 3.30 \\
$\mathrm{FeO}^{\mathrm{a}}$ & 5.67 & 5.34 & 6.58 & 3.21 & 5.22 & 12.35 \\
$\mathrm{MnO}_{\mathrm{MgO}}$ & 0.15 & 0.16 & 0.19 & 0.10 & 0.15 & 0.27 \\
$\mathrm{CaO}$ & 17.90 & 17.24 & 17.06 & 17.79 & 18.10 & 13.64 \\
$\mathrm{Na}{ }_{2} \mathrm{O}$ & 0.19 & 20.42 & 19.69 & 21.12 & 19.53 & 17.78 \\
$\mathrm{TiO}_{2}$ & 0.28 & 0.21 & 0.19 & 0.19 & 0.15 & 0.29 \\
$\mathrm{NiO}^{2}$ & 0.00 & 0.00 & 0.54 & 0.21 & 0.39 & 1.46 \\
$\mathrm{Cr}_{2} \mathrm{O}_{3}$ & 0.52 & 0.35 & 0.37 & 1.06 & 0.23 & 0.10 \\
$\mathrm{Total}^{2}$ & 99.61 & 99.25 & 100.59 & 99.49 & 99.74 & 98.29 \\
En & 50.8 & 49.4 & 48.9 & 51.3 & 51.6 & 40.9 \\
\hline
\end{tabular}

Note: 1, Hole 333A; phenocryst - magma group 1; 2, Hole 333A; microphenocrysts - magma group 1 ( 2 crystals); 3 , Hole 333A; groundmass microlite - magma group 1; 4, Hole 333A; phenocrysts - magma group 3 ( 2 crystals); 5 , Hole $333 \mathrm{~A}$; groundmass microlite - magma group $3 ; 6$, Site 335 ; groundmass microlite - magma group 1.

${ }^{\mathrm{a}}$ Total iron. 
TABLE 6

Average Spinel Compositions, Hole 332B

\begin{tabular}{|c|c|c|}
\hline & Microphenocrysts & $\begin{array}{l}\text { Inclusions } \\
\text { in Olivine }\end{array}$ \\
\hline $\mathrm{FeO}^{\mathrm{a}}$ & 12.49 & 10.97 \\
\hline $\mathrm{MnO}$ & 0.39 & .39 \\
\hline $\mathrm{MgO}$ & 15.01 & 15.98 \\
\hline $\mathrm{Cr}_{2} \mathrm{O}_{3}$ & 43.36 & 44.38 \\
\hline $\mathrm{Al}_{2} \mathrm{O}_{3}$ & 24.17 & 23.85 \\
\hline $\mathrm{Fe}_{2} \mathrm{O}_{3} \mathrm{a}$ & 3.39 & 3.07 \\
\hline $\mathrm{TiO}_{2}$ & 0.35 & .38 \\
\hline Total & 99.16 & 99.02 \\
\hline $\mathrm{Fe}^{+2}$ & 2.540 & 2.222 \\
\hline Mn & 0.081 & 0.081 \\
\hline $\mathrm{Mg}$ & 5.443 & 5.766 \\
\hline $\mathrm{Cr}$ & 8.340 & 8.496 \\
\hline $\mathrm{Al}$ & 6.922 & 6.805 \\
\hline $\mathrm{Fe}^{+3}$ & 0.610 & 0.559 \\
\hline $\mathrm{Ti}$ & 0.064 & 0.070 \\
\hline $\mathrm{O}$ & 32.000 & 32.000 \\
\hline $100 . \mathrm{Mg} /\left(\mathrm{Mg}+\mathrm{Fe}^{+2}\right)$ & 68.2 & 72.5 \\
\hline $100 . \mathrm{Cr} /(\mathrm{Cr}+\mathrm{Al})$ & 54.6 & 55.5 \\
\hline $\begin{array}{l}100 \cdot \mathrm{Fe}^{+3} / \\
\left(\mathrm{Fe}^{+3}+\mathrm{Cr}+\mathrm{Al}\right)\end{array}$ & 3.84 & 3.53 \\
\hline No. of analyses & 6 & 3 \\
\hline
\end{tabular}

enriched in $\mathrm{Al}_{2} \mathrm{O}_{3}$ and $\mathrm{CaO}$ (up to 23 and 16.5 wt \%, respectively) and poorer in $\mathrm{TiO}_{2}, \mathrm{P}_{2} \mathrm{O}_{5}$, and $\mathrm{K}_{2} \mathrm{O}$ for equivalent $\mathrm{MgO}$ contents. They also have markedly higher values of the ratio $100 \times \mathrm{Mg} /\left(\mathrm{Mg}+\mathrm{Fe}^{+2}\right)(>77)$ and higher $\mathrm{Cr}$ abundances. Plagioclase phenocrysts are approximately $\mathrm{An}_{90}$, and olivine microphenocrysts have compositions in the range Fos9-90. Oxide variation diagrams (Figure 3) show that $\mathrm{MgO}$ varies from 5.6 to 8.7 wt \% along a plagioclase accumulation trend. The magnesian noncumulate host liquid was exceptionally rich in $\mathrm{Al}_{2} \mathrm{O}_{3}$ and $\mathrm{CaO}$ and low in LIL-elements, matched only by the noncumulate host of group 332A5 magmas at the base of the section in Hole 332A.

Group 332B-2-This group is represented by about 90 meters of aphyric and sparsely phyric basalt of lithologic unit 2 and about 100 meters of sparsely to coarsely phyric basalts in lithologic unit 3 . Coarsely phyric rocks are rich in plagioclase $\left(\mathrm{An}_{89}\right)$, whereas less phyric specimens have phenocryst assemblages of plagioclase + olivine or plagioclase + olivine + clinopyroxene. $\mathrm{TiO}_{2}$ and $\mathrm{P}_{2} \mathrm{O}_{5}$ contents (Figure 3 ) show that these rocks are related to glass group 332B-a. Oxide variation diagrams suggest some plagioclase accumulation to 2- or 3-phase cotectic compositions. The ratio $100 \times \mathrm{Mg} /\left(\mathrm{Mg}+\mathrm{Fe}^{+2}\right)$ ranges from 64 to 68 .

Group 332B-3-Group 3 comprises a sequence of moderately to coarsely phyric pillow lavas between Core 16, Section 1 and Core 20, Section 1, where they form the upper part of lithologic unit 4. Phenocrysts are chiefly olivine (Fo88-89) and lesser amounts of $\mathrm{Cr}$-spinel. Two whole-rock analyses are available (16-2 and 19-1) which are characterized by $\mathrm{TiO}_{2}$ contents of about 0.75 wt $\%$ and $\mathrm{Al}_{2} \mathrm{O}_{3}$ contents of 14.5 to 15.0 wt \% (Table 2). These lavas are probably associated with glass group 332B-b.

Group 332B-4-Immediately underlying group 332B-3, 332B-4 magmas form the lower part of lithologic unit 4 , down to 465 meters subbasement. They consist of coarsely olivine-phyric (picritic) pillow lavas with common phenocrysts of olivine and $\mathrm{Cr}$ spinel. These lavas have slightly lower $\mathrm{TiO}_{2}(0.69 \mathrm{wt} \%)$ and higher $\mathrm{Al}_{2} \mathrm{O}_{3}$ (14.36 wt \%) than those of group 332B-3, as shown by one analyzed specimen (Core 20, Section 1, 91-95 cm). The associated glasses (group 332B-c) are likewise distinct from those of group 332Bb (Figure 3). Both magma groups are clearly olivine cumulates, and they differ markedly from the low $\mathrm{TiO}_{2}$, high $\mathrm{Al}_{2} \mathrm{O}_{3}$ and $\mathrm{CaO}$ picrites of group 332 $\mathrm{B}-6$ lower in the section.

Group 332B-5-Lithologic unit 5 (465-495 m subbasement) consists of glomerophyric pillow lavas belonging to magma group 332B-5. Prominent aggregates of olivine ( $\left.\mathrm{Fos}_{89}\right)$ and plagioclase $\left(\mathrm{An}_{90}\right)$ are associated with $\mathrm{Cr}$-spinel microphenocrysts and ophitic clinopyroxene. The phenocryst aggregates appear to represent incipient states of in situ crystallization, with little or no differential crystal-liquid movement. Oxide variation (Figure 3 ) suggests these magmas lie on an olivine-control trend. Group 332B-5 magmas are richer in $\mathrm{TiO}_{2}$ and $\mathrm{P}_{2} \mathrm{O}_{5}$ than group 332B-3 or -4 magmas of equivalent $\mathrm{MgO}$ content, but poorer in these elements and richer in $\mathrm{Al}_{2} \mathrm{O}_{3}$ than noncumulate magmas of group 332B-2. Their primitive character is reflected by high ratios of $100 \times \mathrm{Mg} /\left(\mathrm{Mg}+\mathrm{Fe}^{+2}\right)$, which range from 70 to 72 . The distinctive composition of these magmas is also reflected in the associated glasses of group 332B-d (Table 1, Figure 3).

Group 332B-6-Magmas of this group are represented by several diverse lithologies, ranging from olivine-phyric (picritic) to coarsely plagioclase-phyric types, which are interbedded over an interval of more than 200 meters with magmas of other groups. These basalts occur sparsely at the base of lithologic unit 4 , in unit 6 , and frequently in units 7,8 , and 9. They are cumulates of either olivine (Fos8) and Cr-spinel or plagioclase ( $\mathrm{An}_{90}$ ), and range in $\mathrm{MgO}$ content from 7.8 to $25.0 \mathrm{wt} \%$. Average analyses in Table 2 are given for both olivine and plagioclase phyric types (groups 332B$6 \mathrm{~A}$ and $6 \mathrm{~B}$, respectively). Oxide variation for each subgroup suggests their possible derivation from a noncumulate $\mathrm{CaO}$-rich magma, poor in $\mathrm{TiO}_{2}, \mathrm{FeO}, \mathrm{Na}_{2} \mathrm{O}$, and $\mathrm{P}_{2} \mathrm{O}_{5}$, similar to glass compositions of group 332Be (Table 1). Glasses of this composition occur with 332B-6 magmas at about 600 meters subbasement.

Group 332B-7-Major element chemistry of this group is similar to that of 332B-2, but the magmas of group 7 have higher values of $100 \times \mathrm{Cr} /(\mathrm{Cr}+\mathrm{Ni})$ for equivalent values of $100 \times \mathrm{Mg} /\left(\mathrm{Mg}+\mathrm{Fe}^{+2}\right)$ (Figure 8). Five analyzed specimens from this group have relatively low $\mathrm{TiO}_{2}(0.85$ to $1.0 \mathrm{wt} \%)$ and may define a subgroup. $\mathrm{Al}_{2} \mathrm{O}_{3}, \mathrm{CaO}$ and $\mathrm{SiO}_{2}$ variation in these magmas (Figure 3 ) indicates that they are plagioclasecumulative types, which may in part account for their lower $\mathrm{TiO}_{2}$. 

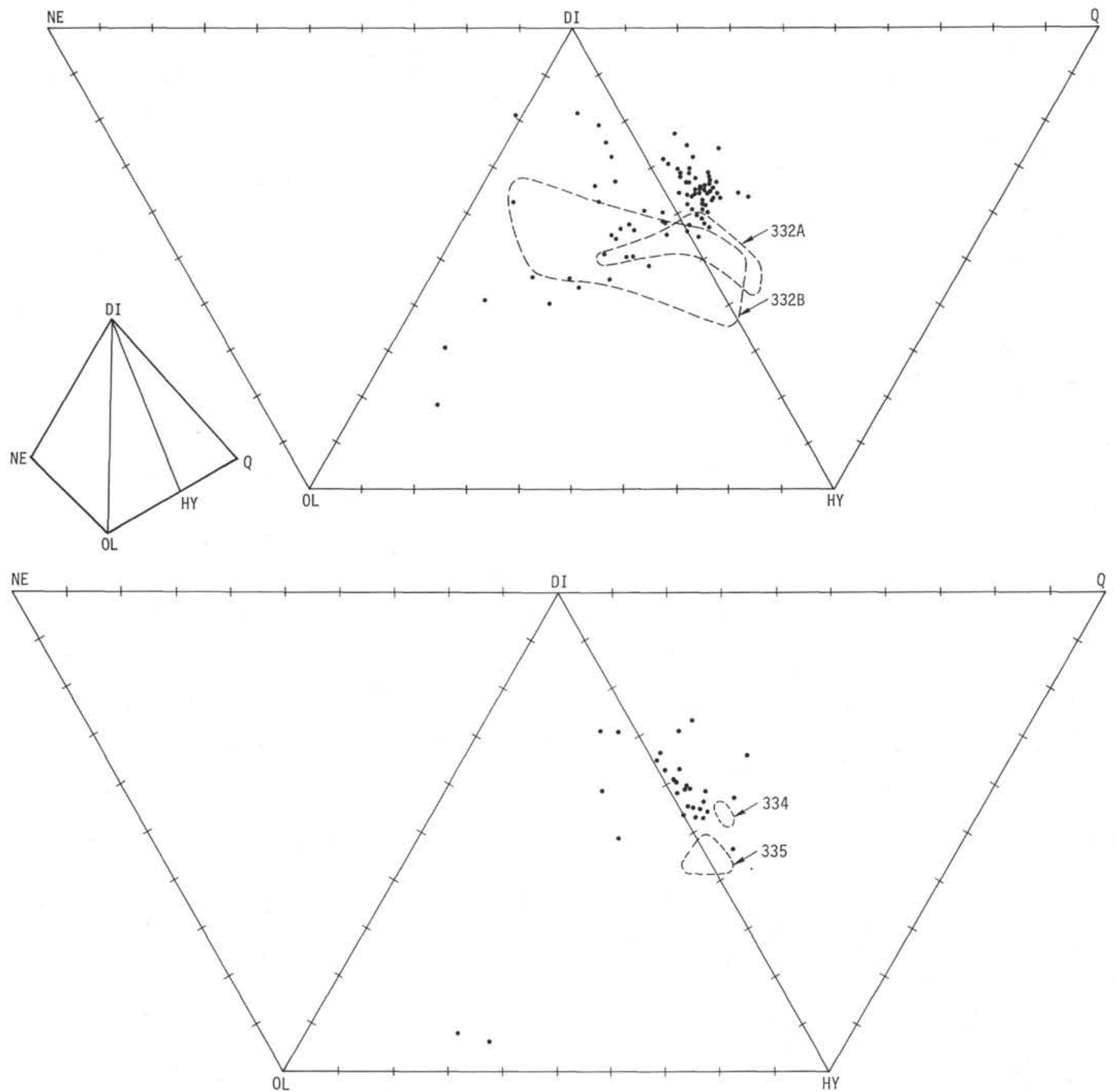

Figure 1. Normative compositions of Leg 37 basalts and plutonic rocks, normalized with $\mathrm{Fe}_{2} \mathrm{O}_{3}=1.5$ wt \%, plotted on the Tilley-Muir diagram; (a) Hole 332A, and 332B, data; (b) Site 334 and 335 data. Dashed lines indicate extent of glass compositions.

The rocks of group 7 range from aphyric to sparsely or highly phyric basalts with phenocrysts of plagioclase (An85-90), olivine (Fo84-89), and sparse clinopyroxene. Group 7 magmas occur in lithologic unit 6 (interbedded with group 332B-6 lavas) and comprise the whole of lithologic units 10 and 11 at the base of the section.

\section{Trace and Minor Element Geochemistry}

The highest LIL-element concentrations occur in groups $332 \mathrm{~B}-2$ and -7 and lowest in cumulate groups
$332 \mathrm{~B}-1$ and -6 , with intermediate contents in groups $332 \mathrm{~B}-3,-4$, and -5 .

$\mathrm{Ti} / \mathrm{Zr}$ ratios range from 70 to 100 and are broadly similar to those for 332A rocks (cf. Figures 6 and 9). As expected, $\mathrm{Sr} / \mathrm{Zr}$ ratios are high in plagioclase cumulate magmas (groups 1 and 6B); the lowest values occur in group 7 magmas which have fractionated plagioclase. $\mathrm{Zr} / \mathrm{Y}$ ratios range from 3.58 to 2.29 in these rocks, being highest in the plagioclase cumulates of group 1 and lowest in the picrites of group 6A. 


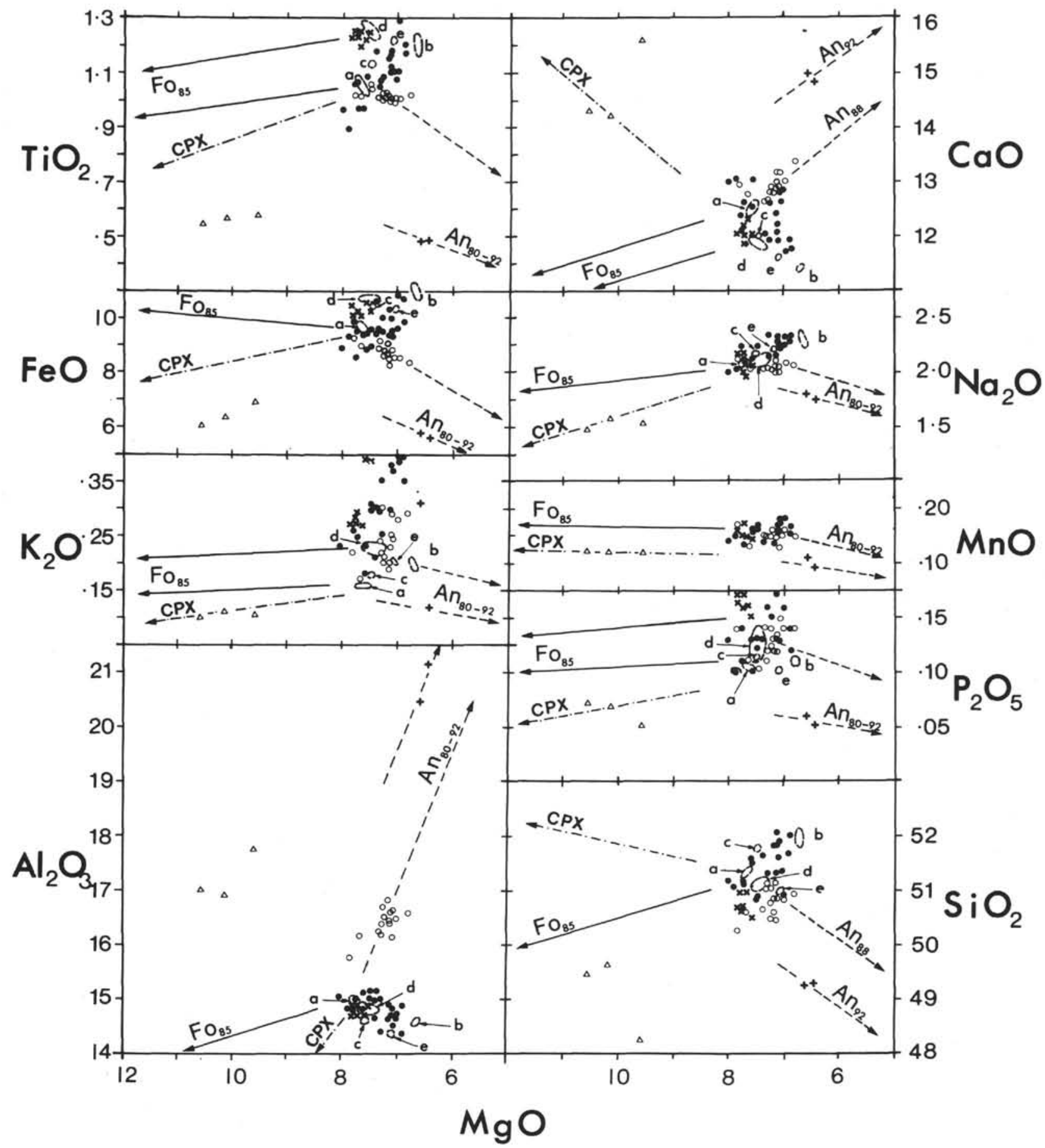

Figure 2. $\mathrm{MgO}$ variation diagrams for Hole $332 \mathrm{~A}$ data, with control trends of fractionating phases and Hole $332 \mathrm{~A}$ glass groups (332A-a to -e) indicated. Whole-rock chemical groups indicated by the following symbols: $332 \mathrm{~A}-1,+$; $332 A-2, \bullet ; 32 A-3, x ; 332 A-4,0 ;$ and $332 A-5, \triangle$ Phenocryst phase control lines: solid $=$ olivine, dot-dash $=$ clinopyroxene, and dash $=$ plagioclase.

Olivine- and plagioclase-cumulate groups lie along lines of approximately equal $\mathrm{P} / \mathrm{Y}$ ratio. However, $\mathrm{P} / \mathrm{Y}$ is strongly fractionated between the noncumulate groups, ranging from 10-15 in group 5 magmas to $17-25$ in groups 2 and 7.

$\mathrm{Rb}$ and $\mathrm{Ba}$ data reflect their mobility during alteration, with $\mathrm{Ba}$ showing less scatter than $\mathrm{Rb}$. Data from the freshest specimens suggest $\mathrm{Ba} / \mathrm{Zr}$ is not greatly fractionated between magma groups.

$\mathrm{Cr}$ abundance is distinctive for each magma group, despite its sensitivity to fractionation by mafic phenocryst phases. Plagioclase cumulates of groups 332B-1 and -6B have $\mathrm{Cr}$ contents of $230-320 \mathrm{ppm}$ and $360-450 \mathrm{ppm}$, respectively (cf. $165-190 \mathrm{ppm}$ for magma 


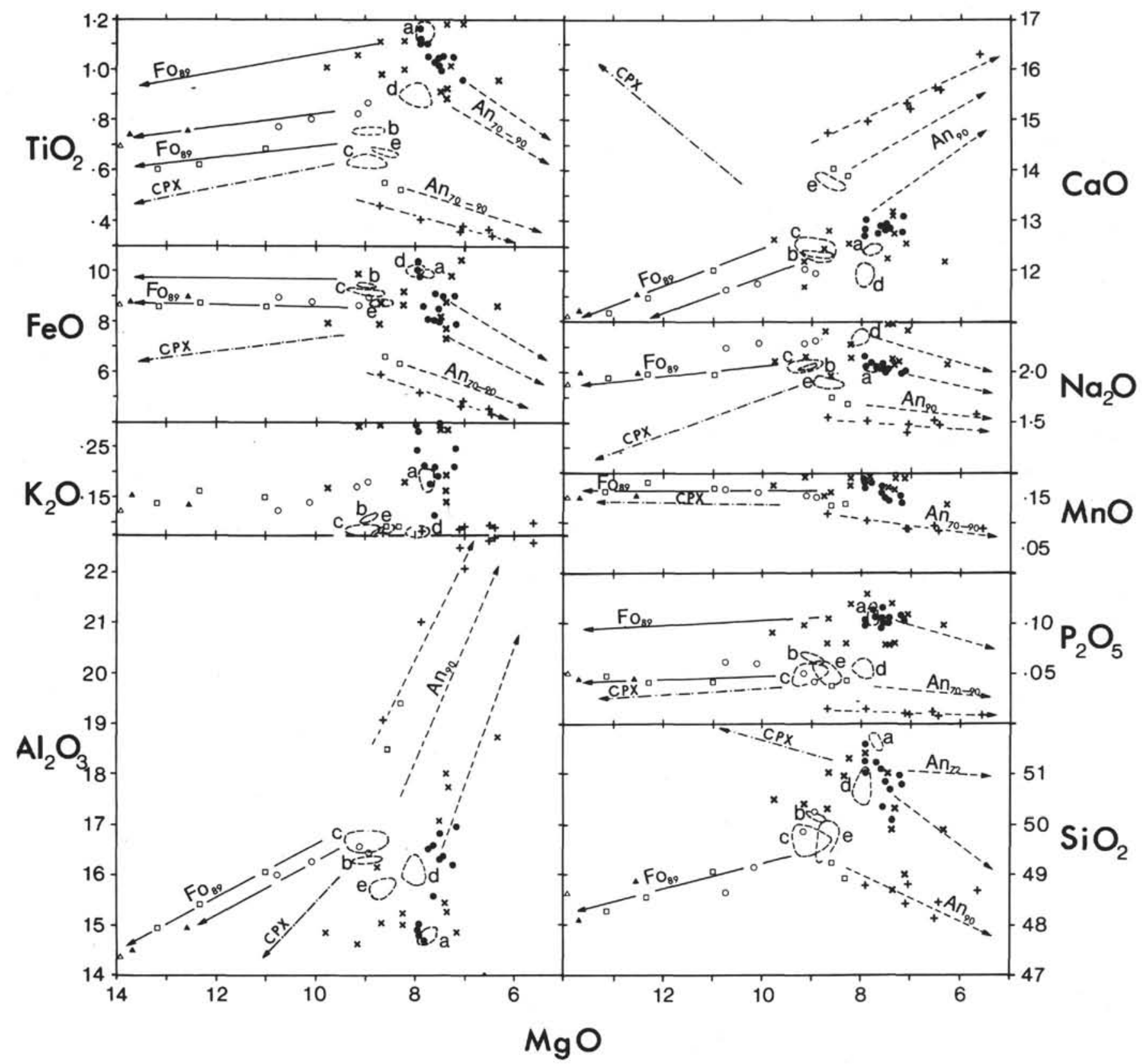

Figure 3. $\mathrm{MgO}$ variation diagrams for Hole $332 \mathrm{~B}$ data, with control trends of fractionating phases and Hole $332 \mathrm{~B}$ glass groups (332B-a to -e) indicated. Whole-rock chemical groups indicated by the following symbols: $332 B-1,+; 332 B-2$, -; 332B-3, 4; 332B-4, $\triangle ; 332 B-5,0 ; 332 B-6 a$, $\square ; 332 B-6 b$, -; and 332B-7a, x. Phenocryst phase control lines: solid = olivine, dot-dash = clinopyroxene, and dash = plagioclase. Note correspondence of composition $X\left({ }^{*}\right)$, (see Table 2). the calculated host for group 332B-1 and group 332A-5 for $\mathrm{TiO}_{2}, \mathrm{Al}_{2} \mathrm{O}_{3}$, and $\mathrm{CaO}$.

group 332A-1). $\mathrm{Cr}$ contents of the three picrite groups $332 \mathrm{~B}-3,-4$, and $-6 \mathrm{~A}$ average 760,890 , and $1300 \mathrm{ppm}$, respectively (cf. 410-540 for the cumulate magmas of group $332 \mathrm{~A}-5$ ). For the mostly noncumulate magmas $\mathrm{Cr}$ content ranges from 180 to $525 \mathrm{ppm}$.

\section{Geochemical Stratigraphy}

Chemical variation with depth shows that each magma group occupies a characteristic stratigraphic position (Figure 10). The most distinctive chemical break occurs at about 400 meters depth-the base of lithologic unit $3 \mathrm{~b}-$ below which there is a varied series of cumulate and noncumulate rock types. Above about 500 meters there is good correlation among chemical groups and lithologic units, with groups $332 \mathrm{~B}-4$ and -3 corresponding to picrite unit 4 , group $332 \mathrm{~B}-2$ to lithologic units $3 \mathrm{~b}, 3 \mathrm{a}$, and 2 , and group 332B-1 to lithologic unit 1 . The lithology of unit $3 b$ suggests a series of microdoleritic intrusions, whereas the succeeding units $3 a$ and 2 are probably an eruptive sequence. Small-scale cyclic variation is evident (Figures 7 and 10) but not as distinctive as that in 332A magmas or in the lower part of Hole 332B. 

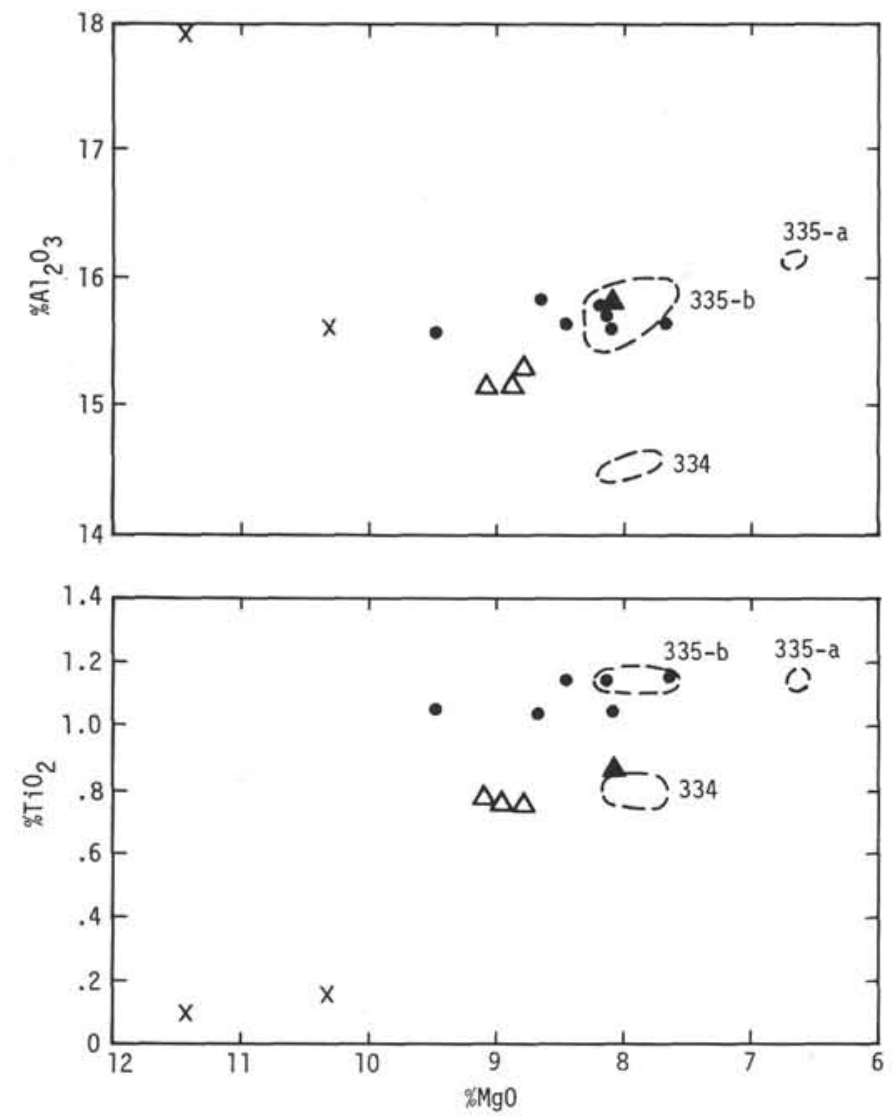

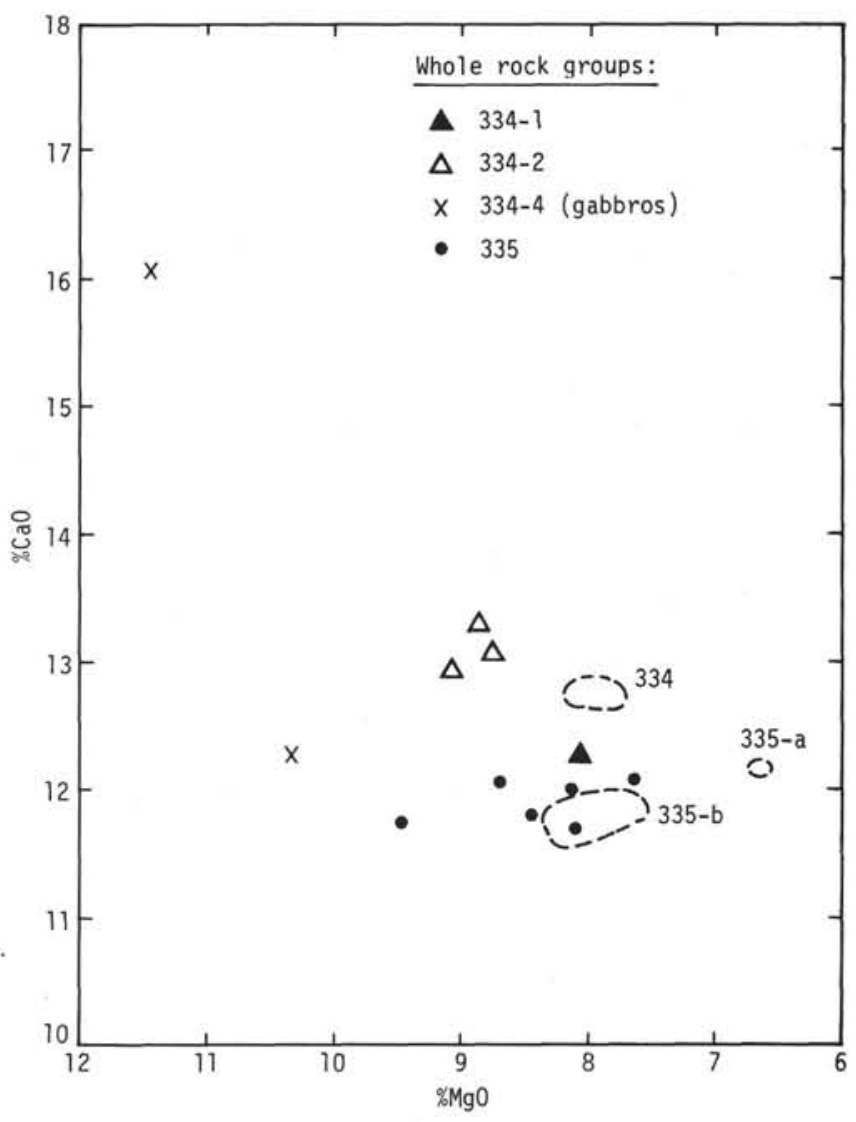

Figure 4. $\mathrm{MgO}$ variation diagrams for $\mathrm{TiO}_{2}, \mathrm{Al}_{2} \mathrm{O}_{3}$, and $\mathrm{CaO}$ from Sites 334 and 335, with magma groups and glass groups shown.

In the interval between 500 and 670 meters the rocks are mostly porphyritic with rapid intercalation of olivine- and plagioclase-phyric types. This is due in part to interbedding of magma types but largely to the extreme fractionation of group 332B-6 magmas. Lithologic unit 5 is composed of group 332B-5 magmas, unit 6 is a complex interbedded unit, units 7 , 8 , and 9 are largely of 332B-6 magma, and units 10 and 11 consist mostly of $332 \mathrm{~B}-7$ magma. Rhythmic variation with depth is most pronounced in group 332B-6 magmas and less so in group $332 \mathrm{~B}-7$ and -5 sequences (Figures 7 and 10).

The lower part of the 332B section was built up by coeval eruption of strongly contrasting magma typeseach fractionated under different conditions. Paleomagnetic stratigraphy (Hall and Ryall, Chapter 16, this volume) indicates closely spaced magnetic units at depths below about 525 meters, with no simple relation to lithology and chemistry. Above this depth, the upper part of magnetic unit M4 corresponds to lithologic unit $5, M 3$ to unit 4, M2 to units $3 \mathrm{a}$ and $3 \mathrm{~b}$, and M1 to unit 1 , each representing a chemically distinct magma type. The chemical and magnetic break at about 408 meters occurs at the top of a continuous 100-meter-thick pillow sequence of group 332B-5, -4 , and -3 magma (Figure 7). This break coincides with a sharp change in oxidation state of the rocks, as reflected by the cationdeficiency of groundmass Fe-Ti oxides (Bleil and Peterson, Chapter 17, this volume). These features reflect a lengthy noneruptive interval, with considerable rockseawater interaction, massive intrusion of the overlying sequence, or a combination of both processes.

\section{Hole 333A}

\section{Lithology}

In this hole 312 meters of basaltic basement were drilled. On the average, coring was done at about 30 meter intervals. Recovery was very poor $(8 \%)$ suggesting that a large part of the section consists of basaltic rubble, breccia, and interbedded sediment. Three principal basalt lithologies were identified on the basis of phenocryst assemblages: olivine phyric, olivine + plagioclase phyric, and olivine + clinopyroxene + plagioclase phyric. Based on varying olivine/plagioclase ratios, the section was divided into seven lithologic units by the shipboard party.

\section{Major Element Geochemistry}

Specimens from each of the seven were analyzed. Variation of $\mathrm{TiO}_{2}, \mathrm{Al}_{2} \mathrm{O}_{3}$, and $\mathrm{CaO}$ versus $\mathrm{MgO}$ suggests the existence of several independent magma types and provides evidence of extensive low pressure fractional crystallization. Five distinct magma types can be recognized and average compositions of these are given in Table 2 . Several analyzed specimens do not fall into any of the recognized groups and may repre- 


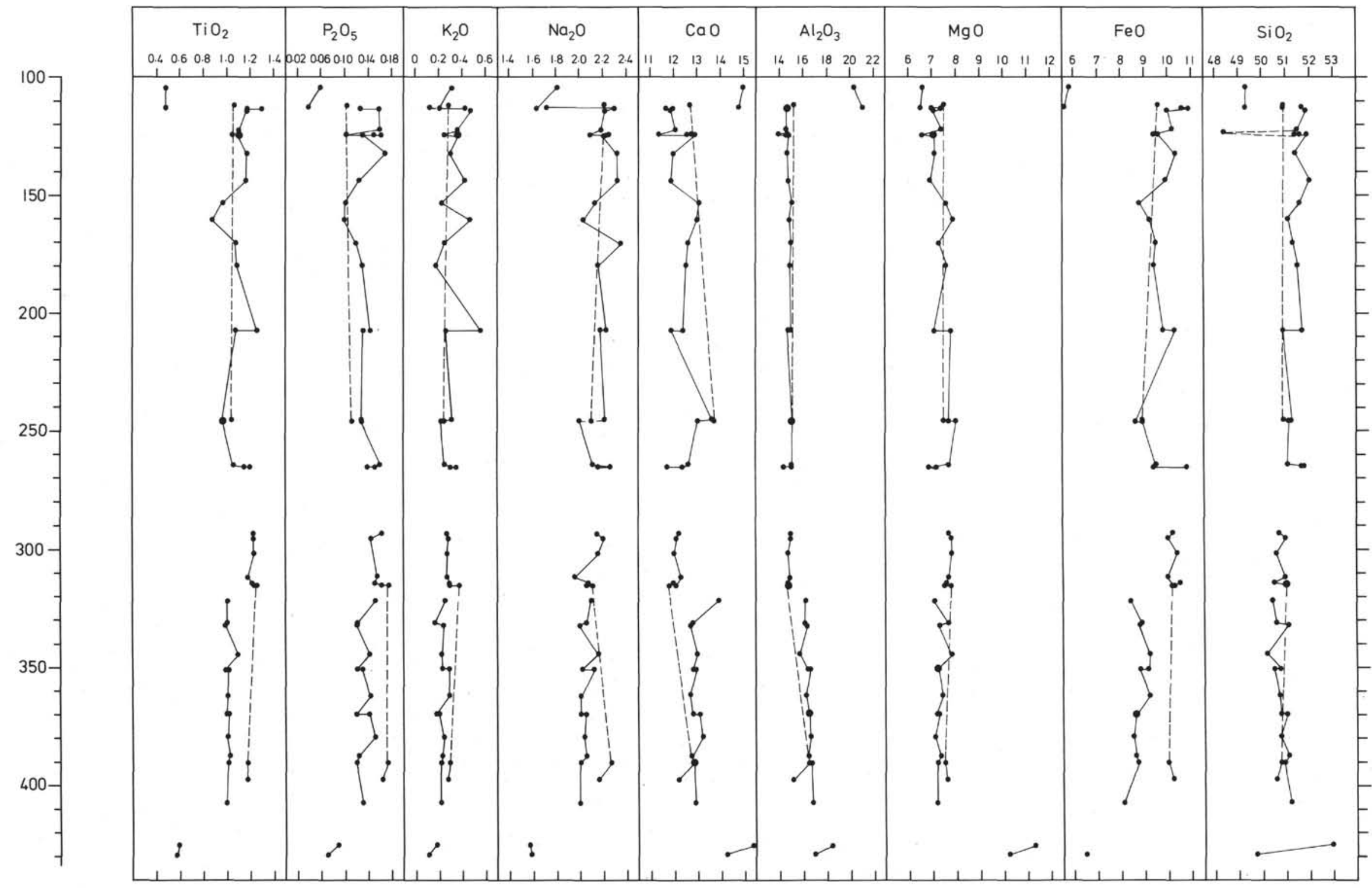

Figure 5. Hole 332A: major element oxides versus subbottom depth in meters indicating vertical extent of magma groups. 


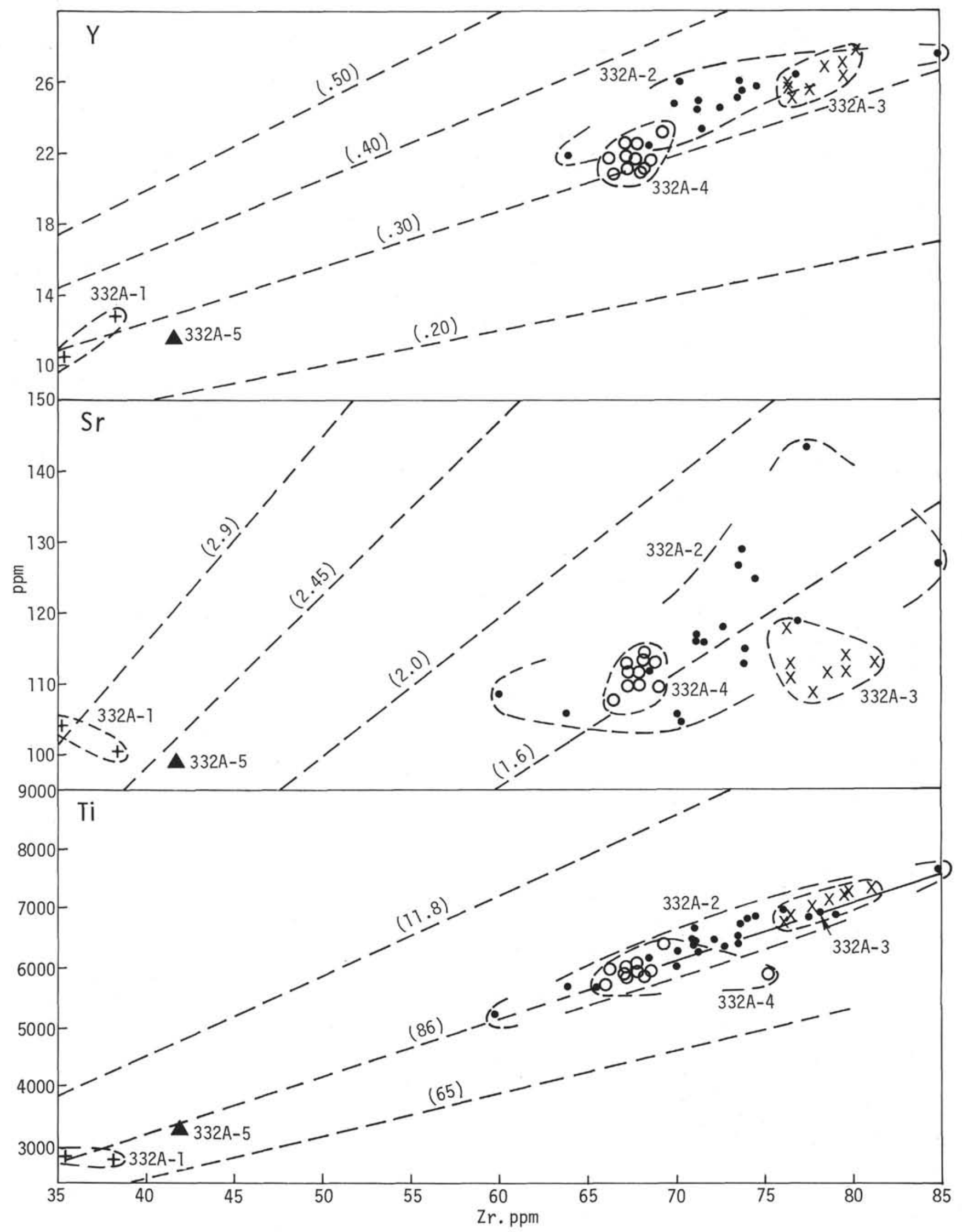

Figure 6. $Y, S r$, and $T i$ versus $\mathrm{Zr}$ for Hole $332 \mathrm{~A}$ rocks; dotted straight lines show equal element; $\mathrm{Zr}$ ratios (quoted in parentheses); whole-rock groups are indicated with same symbols as in Figure 2. 

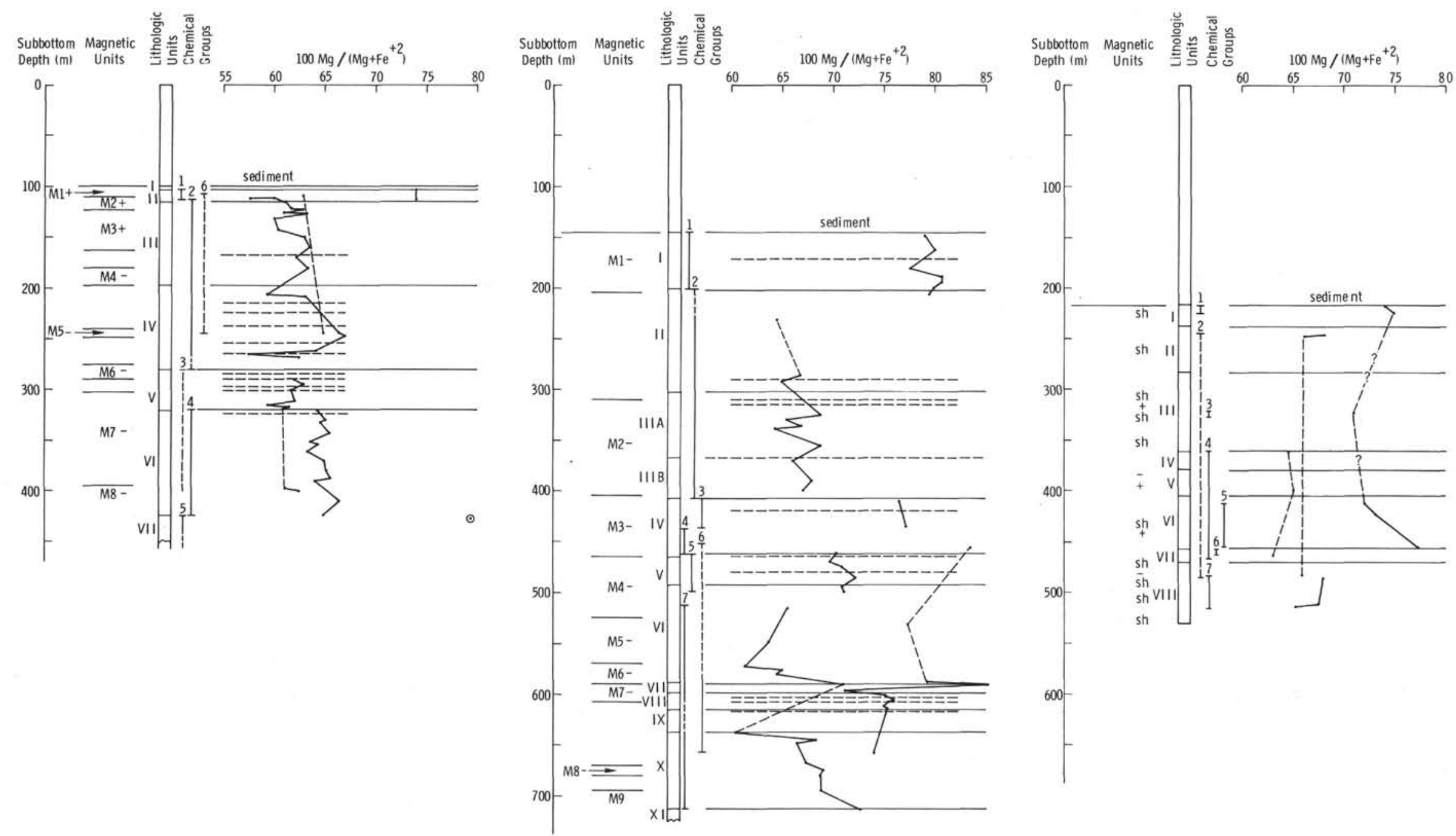

Figure 7. Variation of $100 \times \mathrm{Mg} /\left(\mathrm{Mg}+\mathrm{Fe}^{+2}\right)$ with subbottom depth in meters along side lithology and magnetic stratigraphy for Holes $332 \mathrm{~A}$, 332B, and $333 \mathrm{~A}$. Probable vertical extent of magma groups is indicated. Horizontal dotted lines show the most important sedimentary intercalations in $332 \mathrm{~A}$ and $332 \mathrm{~B}$. lithologic unit boundaries are shown by continuous horizontal lines. Polarity of magnetic units (M) in Holes $332 \mathrm{~A}$ and $332 \mathrm{~B}$ is indicated by + or $-;$ sh in $333 \mathrm{~A}$ denotes shallow NRM inclinations. 


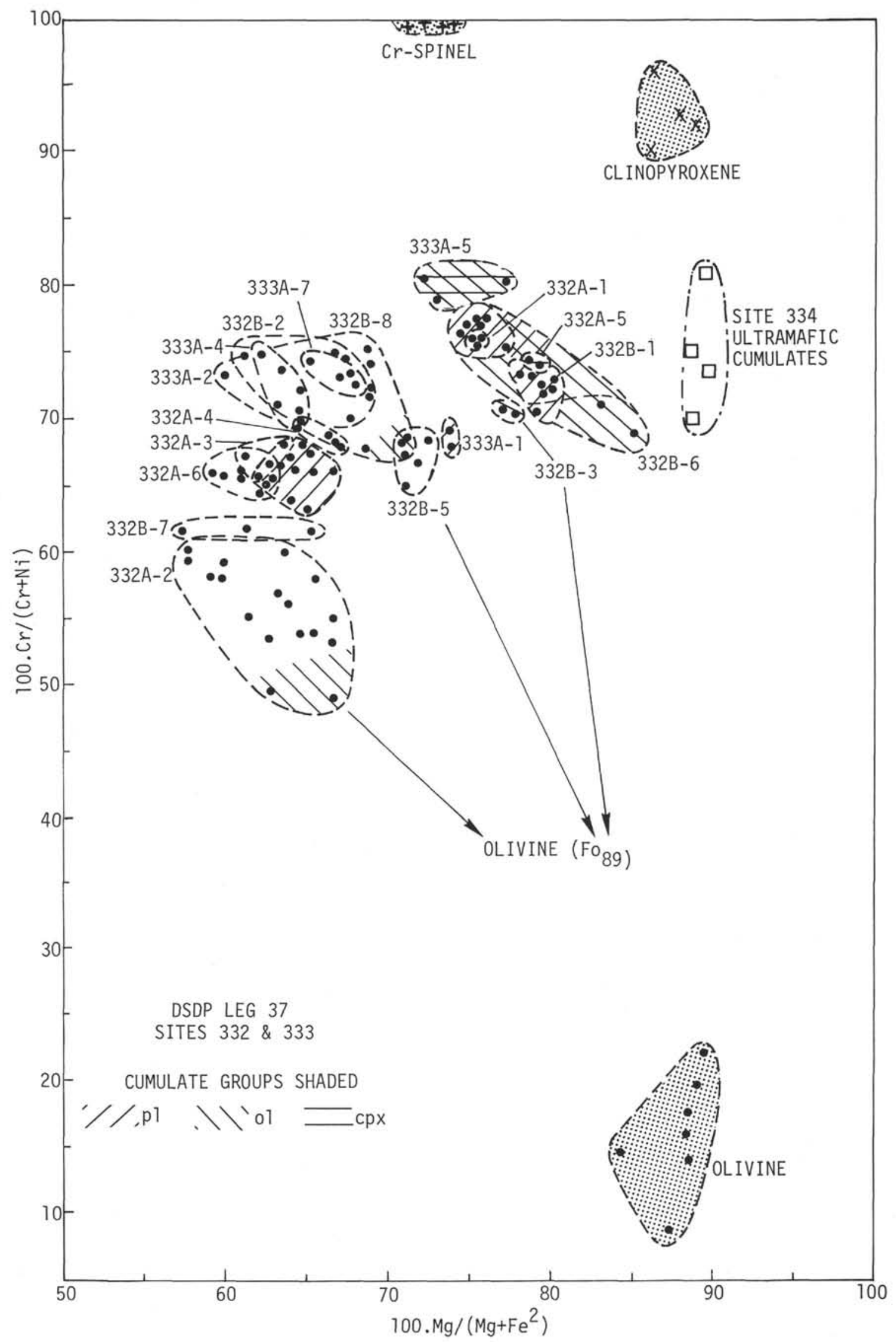

Figure 8. Plots of $100 \times \mathrm{Mg} /\left(\mathrm{Mg}+\mathrm{Fe}^{+2}\right)$ versus $100 \times \mathrm{Cr} /(\mathrm{Cr}+\mathrm{Ni})$ for whole-rock and mineral data from Holes $332 \mathrm{~A}, 332 \mathrm{~B}$, and $333 \mathrm{~A}$; magma groups indicated. 


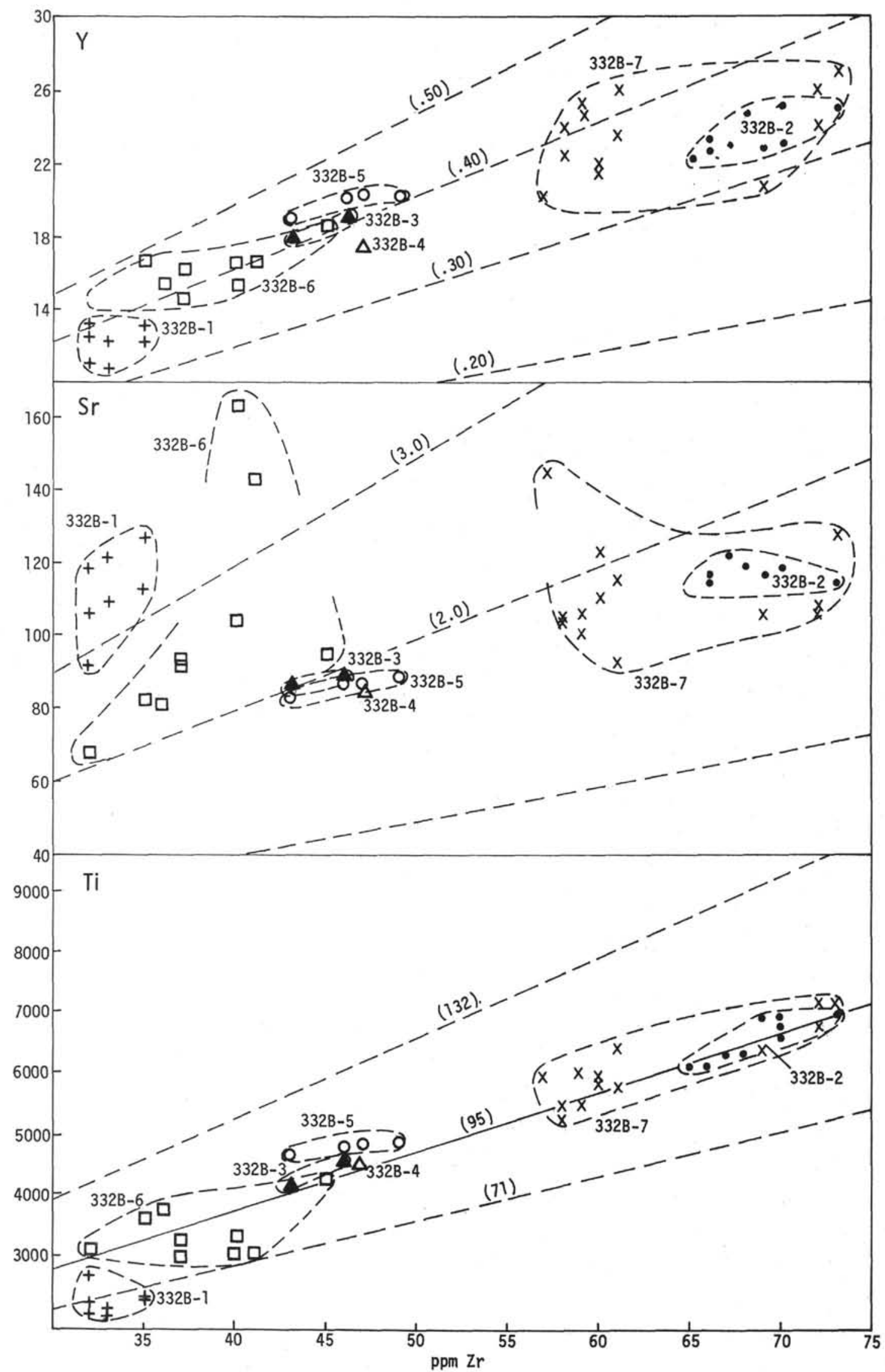

Figure 9. $Y, S r$, and $T i$ versus $Z r$ for Hole $332 B$ rocks; dotted straight lines show equal element/Zr ratios (quoted in parentheses); whole-rock groups are indicated with same symbols as in Figure 3. 


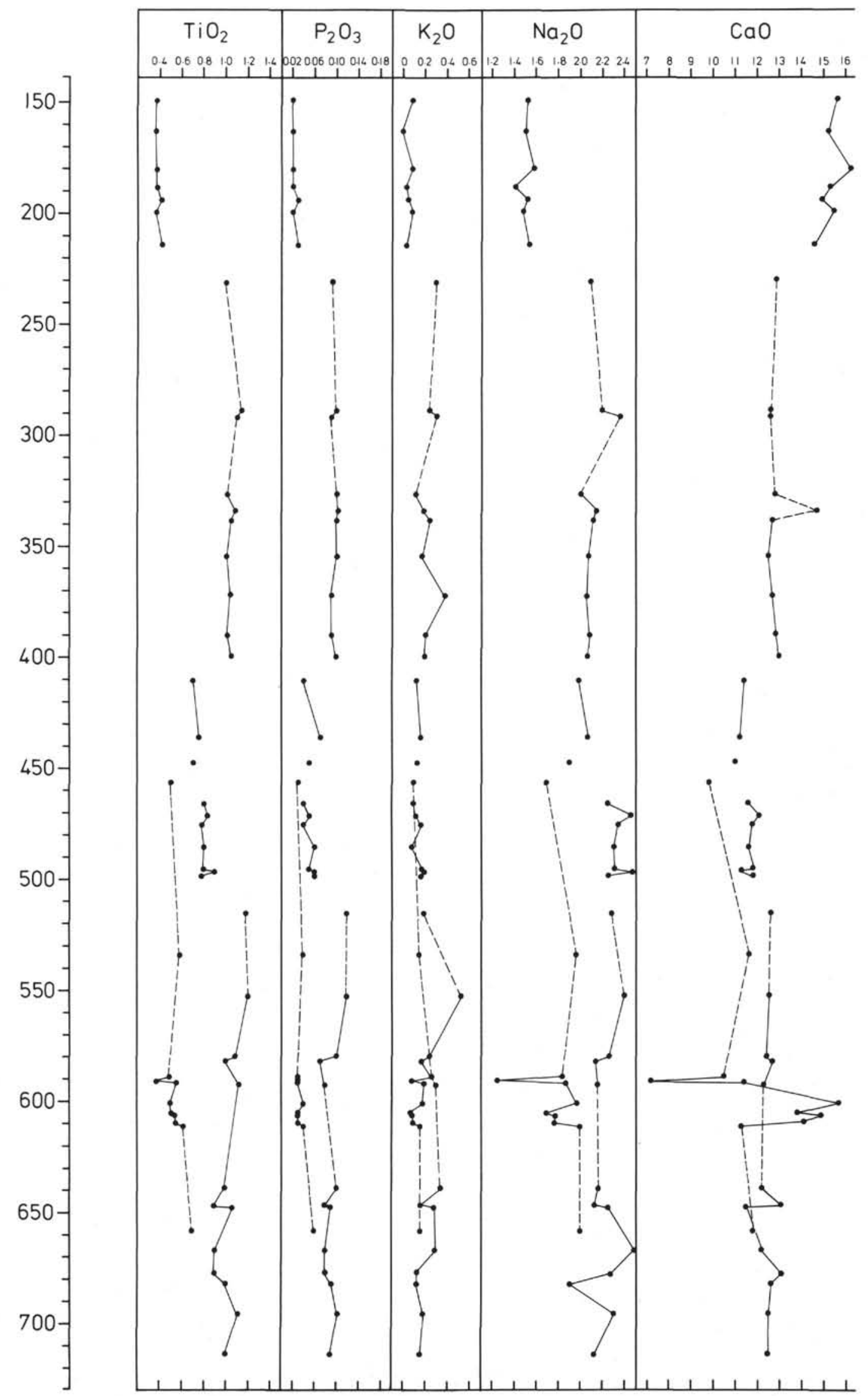

Figure 10. Hole 332B: major element oxides versus subbottom depth in meters, indicating vertical extent of magma groups. 
PETROLOGY AND GEOCHEMISTRY OF IGNEOUS ROCKS

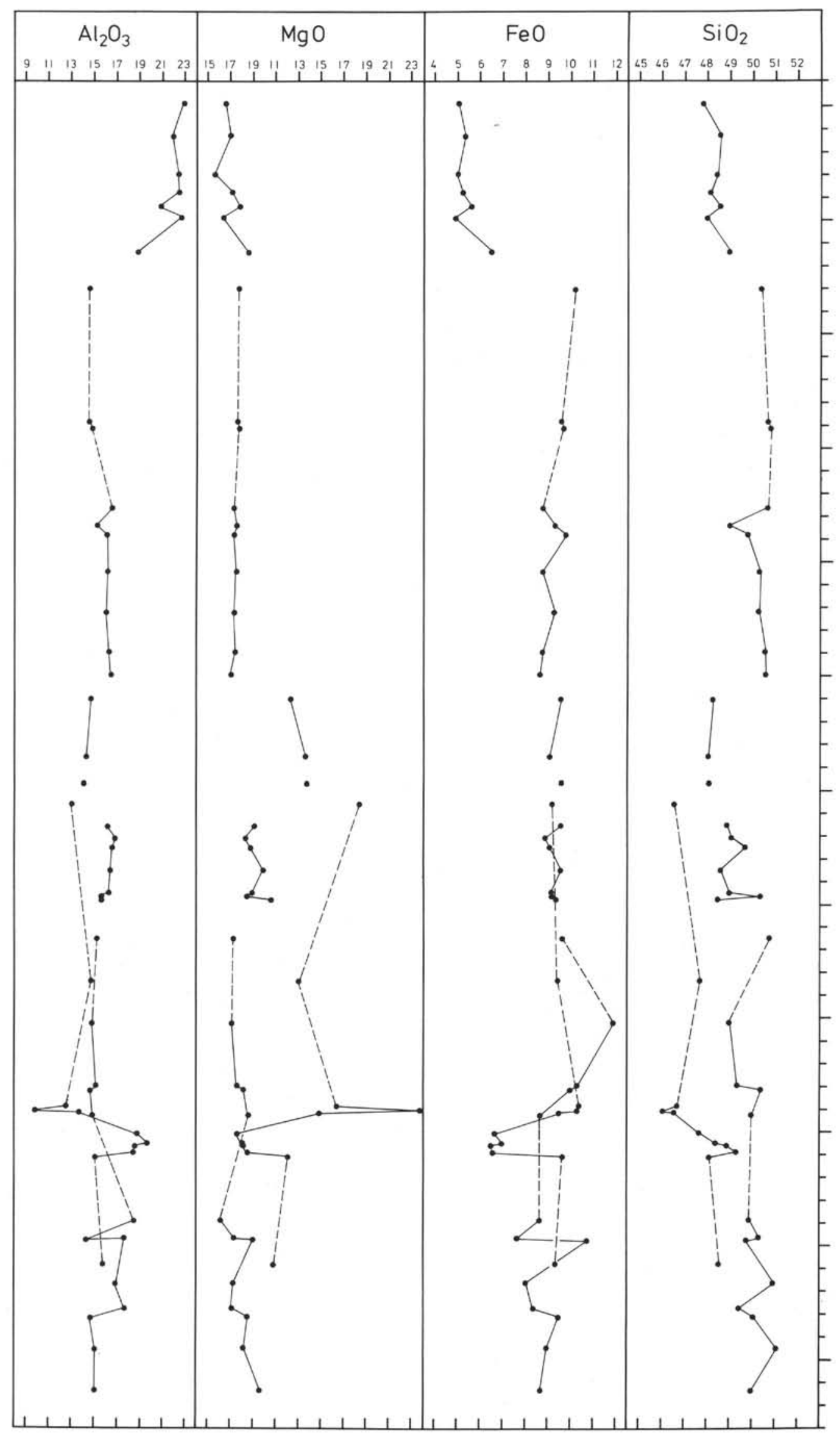

Figure 10. (Continued). 
sent separate chemical types, however, the available data are insufficient to define additional groups.

Group 333A-1-This comprises a series of olivinephyric lavas in lithologic unit 1 with $\mathrm{MgO}$ contents exceeding 10 wt $\%$. These lavas have higher $\mathrm{Al}_{2} \mathrm{O}_{3}$ and $\mathrm{CaO}$ than picritic basalts of Hole $332 \mathrm{~B}$, and phenocrystic olivine has an average composition of Fo86, notably more iron rich than olivines from other picritic units.

Group 333A-2-This group represents a series of sparsely phyric and aphyric basalts in lithologic units 2 and 7. One of the analyzed specimens is a cumulate type with about 15 modal percent of plagioclase phenocrysts; others contain sparse phenocrysts of plagioclase, olivine, and clinopyroxene. These magmas are fairly primitive with $100 \times \mathrm{Mg} /\left(\mathrm{Mg}+\mathrm{Fe}^{+2}\right)$ ratios of 66-68. Parental magmas of this group were clearly lower in $\mathrm{Al}_{2} \mathrm{O}_{3}$ and $\mathrm{TiO}_{2}$ than those of group 1.

Group 333A-3-Group 3 comprises a series of LILelement enriched magmas characterized by $\mathrm{TiO}_{2}$ contents up to 1.3 wt $\%$ and $\mathrm{P}_{2} \mathrm{O}_{5}$ contents between 0.13 and $0.18 \mathrm{wt} \%$. These magmas occur in lithologic units 4,5 , and 7 and are sparsely phyric with small phenocrysts of plagioclase, clinopyroxene, and olivine. $100 \times$ $\mathrm{Mg} /\left(\mathrm{Mg}+\mathrm{Fe}^{+2}\right)$ ratios are below 65 , indicating that these magmas are fairly evolved.

Group 333A-4-Three specimens from lithologic unit 6 comprise this group. These basalts are characterized by high $100 \times \mathrm{Mg} /\left(\mathrm{Mg}+\mathrm{Fe}^{+2}\right)$ ratios (7277), relatively high $\mathrm{Al}_{2} \mathrm{O}_{3}$, and $\mathrm{CaO}$, low $\mathrm{TiO}_{2}$, and moderate $\mathrm{MgO}$ (Table 2). These rocks are moderately phyric with about 10 modal percent of plagioclase, clinopyroxene, and olivine phenocrysts. They are mineralogically and chemically similar to cumulate magmas of group $332 \mathrm{~A}-5$, however, the high $\mathrm{CaO}$ contents (about 15 wt \%) may be partially attributable to the presence of secondary carbonate.

Group 333A-5-This group is represented by three specimens of moderately to sparsely phyric basalt from lithologic unit 8 . Phenocrysts consist chiefly of plagioclase with lesser amounts of clinopyroxene and olivine. For equivalent $\mathrm{MgO}$ contents these magmas are richer in $\mathrm{Al}_{2} \mathrm{O}_{3}$ and poorer in $\mathrm{TiO}_{2}$ than group 333A-3 magmas but form a similar 3-phase cotectic series. Although similar in composition to group 333A2 these magmas have much higher $\mathrm{Cr}$ for a similar range of $100 \times \mathrm{Mg} /\left(\mathrm{Mg}+\mathrm{Fe}^{+2}\right)$ (Table 2).

\section{Trace and Minor Element Geochemistry}

Plots of $\mathrm{Ti}, \mathrm{Sr}$, and $\mathrm{Y}$ versus $\mathrm{Zr}$ are given in Figure 11, with data for eruptive rocks from Sites 334 and 335. $\mathrm{Ti} / \mathrm{Zr}$ ratios for $333 \mathrm{~A}$ groups are approximately the same as for $332 \mathrm{~A}$ and 332B magmas. Marked accumulation of plagioclase is apparent from $\mathrm{Sr} / \mathrm{Zr}$ for one specimen from the $\mathrm{CaO}$ - and $\mathrm{Al}_{2} \mathrm{O}_{3}$-rich magmas of group 333A-4. $\mathrm{Zr} / \mathrm{Y}$ ratios for $333 \mathrm{~A}$ groups are generally in the same range as those for Hole $332 \mathrm{~A}$ groups, and some 332B groups, with no significant intergroup variation (cf. Figures 6 and 11). Significant variation of $\mathrm{P} / \mathrm{Y}$ is observed between some $333 \mathrm{~A}$ groups. Lowest values are for the cumulate group
(333A-4) whereas higher values of $\mathrm{P} / \mathrm{Y}$ characterize the other groups.

\section{Chemical Correlation at Sites $\mathbf{3 3 2}$ and $\mathbf{3 3 3}$}

Holes $332 \mathrm{~A}$ and 332B are located about 100 meters apart in a sediment-filled valley, with basement beneath the site sloping about $6^{\circ}$ to the west. Site 333 lies about $1.8 \mathrm{~km}$ to the southwest in the same valley.

The main lithologic, cheinical, and paleomagnetic features of each hole are compared in Figure 7 against respective subbottom depths. The lack of identity between sections is immediately apparent. Although a few individual samples of similar composition may be identified in each hole, correlation of magma groups is largely unsatisfactory. Considering the ratios $100 \times$ $\mathrm{Mg} /\left(\mathrm{Mg}+\mathrm{Fe}^{+2}\right)$ and $100 \times \mathrm{Cr} /(\mathrm{Cr}+\mathrm{Ni}$ ) (Figure 8 ), groups 332B-7 and 332A-3 and -4 appear to correlate, although $\mathrm{Zr} / \mathrm{Y}$ and $\mathrm{P} / \mathrm{Y}$ ratios are at variance (Table 2). Groups 332B-1 and 332A-5 show some chemical similarities. Both are characterized by high $\mathrm{Zr} / \mathrm{Y}$ and low $\mathrm{P} / \mathrm{Y}$ ratios (Table 2, Figure 6); however, the mineralogy of these two units is quite different.

Groups 332B-2 and 332A-3 are somewhat different in their major element compositions, but they have similar ratios of $\mathrm{Zr} / \mathrm{Y}$ and $\mathrm{P} / \mathrm{Y}$ (Table 2). The 332B-2 magmas have higher ratios of $100 \times \mathrm{Cr} /(\mathrm{Cr}+\mathrm{Ni})$. These two groups could be related by fractionation of $\mathrm{Cr}$-rich phases such as pyroxene or spinel, although there is little evidence of this from phenocryst assemblages, and no indication from within-group variation. However, pyroxene-dominated fractionation at high pressure could possibly account for this discrepancy.

Of the Hole 333A magma groups, 333A-5 may be tentatively matched with $332 \mathrm{~B}-2$, and $333 \mathrm{~A}-4$ with 332B-6 (Table 2). No other groups can be correlated in all respects, but some might be related by high pressure fractionation processes.

Poor geochemical and paleomagnetic correlations may reflect very localized eruptive centers and fractionation systems, restricted lateral flow of lava, or faulting between sites. Lack of correlation between Sites 332 and 333 may also be due to the very poor recovery at the latter site.

\section{Site 334}

\section{Lithology and Geochemistry}

The drilled basement consists of about 50 meters of basalt overlying a melange of gabbro and peridotite at least 67 meters thick. Recovery in the basement section was about $20 \%$.

Two lithologic units are recognized in the basalts; an upper sequence of sparsely phyric basalt with phenocrysts of plagioclase, clinopyroxene, and olivine, and a lower sequence of aphyric basalt. Sedimentary intercalations, breccia zones, and glass rinds are common throughout the basalts.

Four basalt specimens were analyzed from this site, one from the phyric sequence and three from the aphyric unit. The phyric basalts (group 334-1) are dis- 


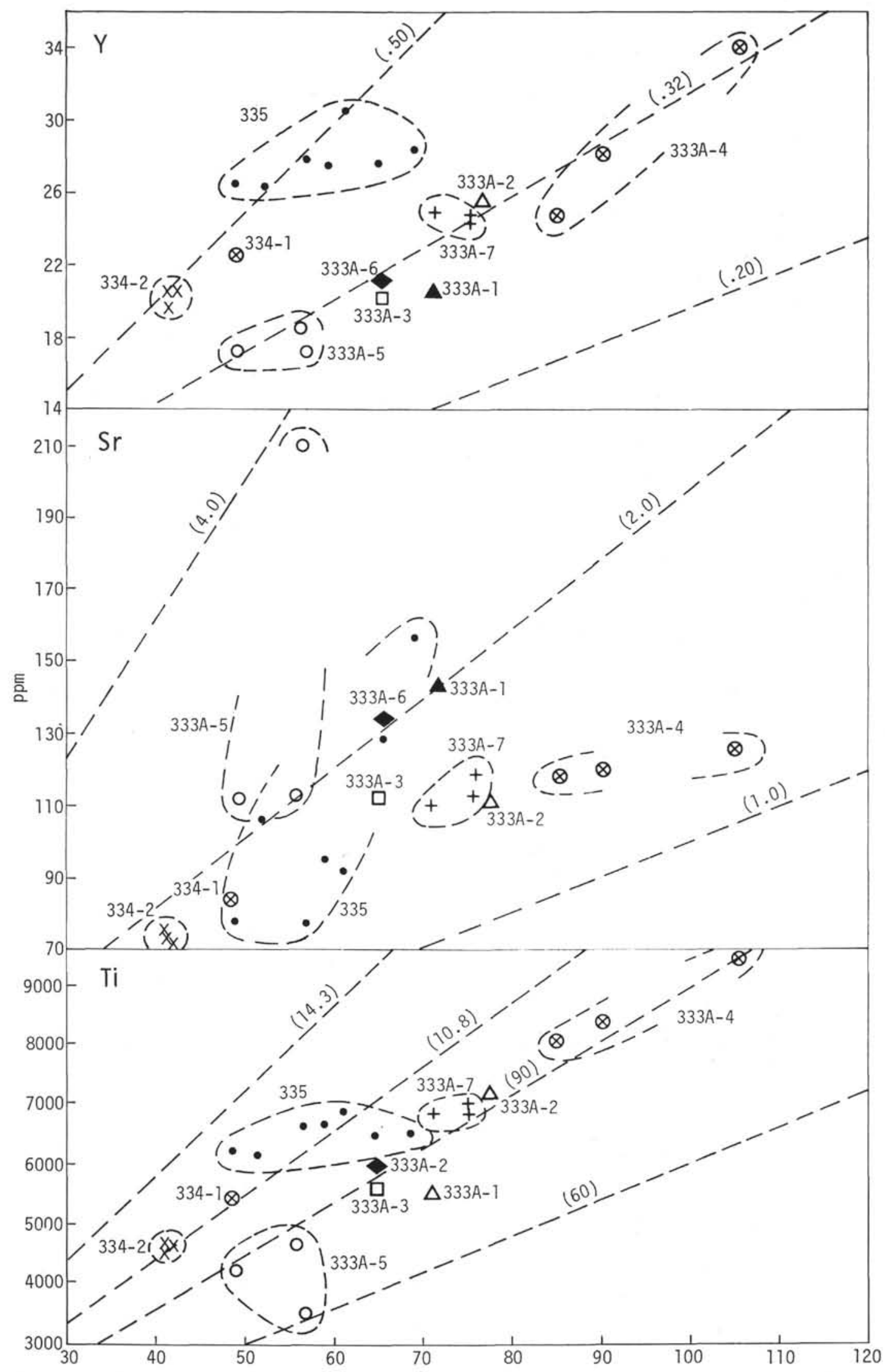

Figure 11. $Y, \mathrm{Sr}$, and $\mathrm{Ti}$ versus $\mathrm{Zr}$ for 333A, 334, and 335 lavas; dotted straight lines show equal element/Zr ratios (quoted in paratheses); whole-rock groups are indicated with symbols for $333 \mathrm{~A}$ as follows: $333 A-1,4 ; 333 A-2, \triangle ; 333 A-3, \square ; 333 A-4, \otimes ; 333 A-5,0 ; 333 A-6$, $;$ and $333 A-7, \mathrm{X}$, Symbols fon 334 iand 335 specimens are: $334-1,{ }^{\otimes} ; 334-2, \mathrm{X}$; and 335 , 
tinctly richer in LIL-elements and $\mathrm{Al}_{2} \mathrm{O}$, than the aphyric types (group 334-2) (Table 2), although both groups are characterized by intermediate LIL-element and relatively low $\mathrm{Al}_{2} \mathrm{O}$ abundance compared to lavas from Holes 332A, 332B, and 333A. The two magma groups do not appear to be related by low pressure fractionation because the glasses of group 1 are lower in both $\mathrm{MgO}$ and $\mathrm{Al}_{2} \mathrm{O}_{3}$ than the whole-rock specimens of group 2 (Figure 4). The phyric basalts were probably derived from a separate, more alumina-rich magma than that represented by the aphyric basalts.

$\mathrm{Ti} / \mathrm{Zr}$ ratios for both groups are marginally higher than in magmas at Holes $332 \mathrm{~A}$ and $332 \mathrm{~B}$, whereas $\mathrm{P} / \mathrm{Y}$ and $\mathrm{Zr} / \mathrm{Y}$ ratios are both relatively low (Figure 11; Table 2). Group 334-1 magmas have higher $\mathrm{Cr}$ contents, but lower $100 \times \mathrm{Mg} /\left(\mathrm{Mg}+\mathrm{Fe}^{+2}\right)$ ratios (68) and lower $\mathrm{MgO}$ contents than group 334-2 magmas.

The plutonic rocks comprise an interlayered sequence of very coarse grained, two-pyroxene gabbro, olivine gabbro, and lesser amounts of peridotite, with numerous intercalated breccia zones. The breccias consist entirely of plutonic rock fragments and may have a matrix of nannofossil chalk. There is a suggestion of rhythmic layering in the plutonic sequence, but the relatively low recovery and the presence of numerous breccia zones make this interpretation uncertain.

Three gabbros and two peridotites were analyzed from the plutonic complex. The gabbros consist of coarse-grained hypidiomorphic aggregates of plagioclase, clinopyroxene \pm orthopyroxene, and minor olivine with small inclusions of chrome spinel. The olivine is partly serpentinized and the pyroxenes are marginally altered to green amphibole. Primary cumulate textures are characteristic.

Primary minerals in the peridotites are chiefly olivine and clinopyroxene \pm orthopyroxene, with minor chrome-spinel and plagioclase. Pyroxenes are marginally altered to amphibole and olivine exhibits varying degrees of serpentinization, correlated largely with the modal percent of olivine in the rock. Textural evidence suggests that the peridotites also originated as cumulates. Olivine compositions in the peridotites (Fos:-89) are similar to those of phenocrysts in mafic lavas (e.g., picrite cumulates at Hole 332B), but are not significantly different from olivine in possible harzburgitic residua from partial melting (Green, 1970). The presence of orthopyroxene in the 4-phase (olivine + clinopyroxene + orthopyroxene + plagioclase) assemblage may indicate crystallization pressures of up to $7.5 \mathrm{kbar}$ (Kushiro and Thompson, 1972), although textural evidence suggests that orthopyroxene was not a liquidus phase. Pyroxenes in both peridotites and gabbros exhibit well-developed exsolution textures which reflect slow cooling of the body.

Chemically the gabbros are somewhat similar to the overlying basalts in composition (magma group 334-3, Table 2), but $100 \times \mathrm{Mg} /\left(\mathrm{Mg}+\mathrm{Fe}^{+2}\right)$ ratios range from 69 to 91 , the exceptionally high values being attributable to accumulation of mafic phases. Their most notable feature, compared to the basalts, is the very low LIL-element contents (e.g., $\mathrm{TiO}_{2}=0.6-0.7 \mathrm{wt} \% ; \mathrm{K}_{2} \mathrm{O}$ $=0.01 \mathrm{wt} \%$ ), and low values of $\mathrm{Zr} / \mathrm{Y}$ and $\mathrm{P} / \mathrm{Y}$ (Table
2). The peridotites are also poor in LIL-elements (magma group 334-4, Table 2) and have $100 \times$ $\mathrm{Mg} /\left(\mathrm{Mg}+\mathrm{Fe}^{+2}\right)$ ratios in the range 88-91, similar to those predicted for material of "pyrolite" composition (Green and Ringwood, 1967).

Site 335

\section{Lithology and Geochemistry}

At this site drilled basement consists of about 107 meters of uniform, sparsely to moderately phyric, pillow basalt with numerous sedimentary intercalations and glass cooling rinds. Phenocrysts range from 1 to 5 modal percent and are mostly plagioclase $\left(\mathrm{An}_{87}\right)$ with minor olivine (Fo88).

Seven whole-rock analyses were made from this sequence. These comprise a single magma group confirming the chemical uniformity of the sequence (Table 2). For an average $\mathrm{MgO}$ content of $8.5 \mathrm{wt} \%$, LILelement contents are intermediate compared to basalts at Holes $332 \mathrm{~A}$ and $332 \mathrm{~B}\left(\mathrm{TiO}_{2}=1.11 \mathrm{wt} \%\right)$ but slightly higher than for Site 334 eruptive rocks (Figure 4). P/Y and $\mathrm{Zr} / \mathrm{Y}$ ratios are relatively low (Table 2). Ratios of $100 \times \mathrm{Mg} /\left(\mathrm{Mg}+\mathrm{Fe}^{+2}\right)$ range from 62 to 69 , reflecting some removal of mafic phases prior to eruption. $\mathrm{Cr}$ contents are relatively high (cf. 334-1 in Table 2) compared to noncumulate magmas at Holes 332A and 332B for equivalent $\mathrm{MgO}$ content.

Rhythmic variation of major element oxides, $100 \times$ $\mathrm{Mg} /\left(\mathrm{Mg}+\mathrm{Fe}^{+2}\right), \mathrm{Cr}$, and $\mathrm{Ni}$ with depth suggests cyclic eruptions similar to those observed at Holes $332 \mathrm{~A}$ and $-B$. Due to relatively small penetration we have little idea as to how representative this 13 (?) m.y. old section is of layer 2. The apparent simplicity of lithologic and geochemical variation contrasts with other sites drilled on Leg 37.

\section{SUMMARY AND DISCUSSION}

Basaltic rocks drilled during Leg 37 conform in a general way to the type Mid-Ocean Ridge Basalt (MORB) as characterized by Melson et al. (1975). However, the chemical variation at Sites 332 and 333 alone is probably as great as that among all hitherto sampled MORB types. At Site 334 a 50 -meter-thick lava series overlies a layered plutonic complex, probably formed by crystal accumulation at considerable depth (up to about $20 \mathrm{~km}$ ). Basement at the oldest site, 335 , consists of a relatively uniform pillow lava sequence.

\section{Low Pressure Fractionation}

Projections of normative chemistry (Figure 12) indicate that low pressure (up to $1 \mathrm{kbar}$ ) fractionation involved the phenocryst assemblages olivine \pm spinel, olivine + plagioclase \pm spinel, and olivine + plagioclase + clinopyroxene. Three-phase cotectic fractionation was confirmed in magma groups $332 \mathrm{~A}-2,-3$, -5 , and $-6,332 \mathrm{~B}-2,-7$, and $333 \mathrm{~A}-2,-4$, and -5 , by the occurrence of green clinopyroxene phenocrysts together with plagioclase and olivine (cf. Frey et al., 1974). Except for group 334-2, magma compositions generally 
plot away from ol $+\mathrm{cpx}$ and plag $+\mathrm{cpx}$ low pressure cotectics and appear to be largely controlled by variations in ol, ol + plag, and (ol) + plag + cpx with minor spinel in the most mafic liquids.

Within-group decrease of $100 \times \mathrm{Mg} /\left(\mathrm{Mg}+\mathrm{Fe}^{+2}\right)$ is accompanied either by an increase of $100 \times \mathrm{Cr} / \mathrm{Cr}+$ $\mathrm{Ni}$ ) (if olivine is the predominant fractionating mafic phase) or by constant $100 \times \mathrm{Cr} /(\mathrm{Cr}+\mathrm{Ni}$ ) (if clinopyroxene accompanies olivine) (Figure 8). These two ratios would not be affected by addition or subtraction of plagioclase, so that plagioclase-cumulate magmas should retain the ratios of their noncumulate host liquids. In this respect the close correspondence of plots for groups $332 \mathrm{~A}-5$ and $332 \mathrm{~B}-1$ magmas is significant (Figure 8).

\section{High Pressure Fractionation}

Magmas similar in their LIL-element character (i.e., element abundances, $\mathrm{P} / \mathrm{Y}, \mathrm{Zr} / \mathrm{Y}$, etc. ratios), but different in their $100 \times \mathrm{Cr} /(\mathrm{Cr}+\mathrm{Ni})$ and $\mathrm{Cr} / \mathrm{Mg}$ ratios, might be related by small degrees of fractional crystallization at greater depths (cf. Kilauea; Wright and Fiske, 1971). Melting relations established by Kushiro and Thompson (1972) for a magnesian abyssal olivine tholeiite indicate 4-phase $(\mathrm{ol}+$ plag $+\mathrm{cpx}+$ opx) coprecipitation at $7.5 \mathrm{kbar}$ and $1215^{\circ} \mathrm{C}$. If such a magma is primary (it has $100 \times \mathrm{Mg} /\left(\mathrm{Mg}+\mathrm{Fe}^{+2}\right)=$ $68.4)$, and its melting relations are characteristic of other primitive mid-ocean ridge basalts, fractionation of garnet-bearing assemblages (e.g., "eclogite," O'Hara, 1968b, 1973) is unlikely in the pressure range considered. Fractionation of ol + plag $+\operatorname{cpx} \pm$ opx would be expected, resulting in cumulates of the type encountered at Site 334. Fractional crystallization dominated by pyroxene would reduce the ratio $100 \times$ $\mathrm{Mg} /\left(\mathrm{Mg}+\mathrm{Fe}^{+2}\right)$, and the $\mathrm{Cr}$ and $\mathrm{Ni}$ contents with concomitant decrease of the ratio $100 \times \mathrm{Cr} /(\mathrm{Cr}+\mathrm{Ni})$ and increase of LIL-element concentrations.

Variation of $100 \times \mathrm{Mg} /\left(\mathrm{Mg}+\mathrm{Fe}^{+2}\right)$ versus $100 \times$ $\mathrm{Cr} /(\mathrm{Cr}+\mathrm{Ni}$ ) for Hole 332A and 332 B magmas (Figure 8 ) indicates that such a model is plausible in relating magma groups $332 \mathrm{~B}-2$ and $332 \mathrm{~A}-3$, the latter being more enriched in LIL-elements. In fact, the immediate high pressure derivative from group 332B-2 would be the parent to group $332 \mathrm{~A}-3$, from which the group $332 \mathrm{~A}-4$ plagioclase-cumulates were derived. Other groups cannot be related by fractionation of pyroxenebearing assemblages if they do not show consecutive increase in LIL-elements with decrease of $100 \times \mathrm{Cr} /(\mathrm{Cr}$ $+\mathrm{Ni})$ and $100 \times \mathrm{Mg} /\left(\mathrm{Mg}+\mathrm{Fe}^{+2}\right)$ ratios.

Adiabatic cooling of high pressure cotectic liquids would bring them well within the olivine primary phase volume at low pressures (O'Hara, 1968b), assuming they were not formed under hydrous conditions (discussed below). The preliminary models presented here will be tested by petrologic mixing calculations (Wright and Doherty, 1971).

\section{Primary Magmas}

The most primitive (i.e., unfractionated) magmas at Holes 332A and 332B are the noncumulate type groups $332 \mathrm{~B}-2$ and -5 (Table 2), together with host magmas to cumulate groups $332 \mathrm{~B}-1,-3,-4,-6$ and $332 \mathrm{~A}-1$ and -5 . Disregarding olivine cumulate compositions, the range of $100 \times \mathrm{Mg} /\left(\mathrm{Mg}+\mathrm{Fe}^{+2}\right)$ for these magmas is about $68-75$, which corresponds with the range predicted by Green (1970) for liquids which equilibrated with peridotite of "pyrolite" composition, and observed olivine phenocryst compositions Fo ${ }_{8-90}$ (Green, 1970; Roeder and Emslie, 1970).

O'Hara (1968a) concluded that most "abyssal tholeiites" do not lie on the boundary of the primary phase volume of orthopyroxene at any pressure, and so cannot be derived from an enstatite-bearing upper mantle if they are primary liquids. Nevertheless, Kushiro and Thompson (1972) showed that abyssal olivine tholeiite could have equilibrated with plagioclase lherzolite at depths up to about $26 \mathrm{~km}$. Consequently, we believe that the most magnesian magmas of some groups (e.g., 332B-2, -5) were erupted to the surface without significant fractional crystallization. However, some portions of these and other magma batches were trapped and subsequently fractionated to a greater or lesser extent. It is significant that compositional extremes (i.e., high $\mathrm{Al}_{2} \mathrm{O}_{3}$, low LILelement- and low $\mathrm{Al}_{2} \mathrm{O}_{3}$, high LIL-element- types) occur at one site (332) in sections that were probably built up in less than $200,000 \mathrm{yr}$. The highly aluminous and LIL-depleted parent(s) to magma groups $332 \mathrm{~A}-5$ and 332B-1 are possibly the most characteristic of "oceanic" tholeiite (cf. Engel et al., 1965; Nicholls, 1965) of Leg 37 basalts. Unfortunately we have no data for glassy (liquid) representatives, although Frey et al. (1974) report a highly aluminous and mafic glass from the South Atlantic (age about 40 m.y.), with $\mathrm{Al}_{2} \mathrm{O}_{3}$ content of $17.4 \mathrm{wt} \%$ and $\mathrm{MgO}=9.81 \mathrm{wt} \%$ (F in Table 2). The origin of such liquids has been a subject of some speculation (Engel et al., 1965; Nicholls, 1965; Green and Ringwood, 1967).

Anhydrous experimental melting studies of a phenocryst-free high-alumina tholeiite from the MAR (Tilley et al., 1972) show plagioclase on the liquidus at 1 atm. Experiments on the same specimen at high pressure (Kushiro and Thompson, 1972) show plagioclase to be replaced by clinopyroxene on the liquidus, without any appearance of olivine. Thus olivine fractionation under anhydrous conditions could not produce this liquid composition. Experiments under hydrous conditions indicate olivine together with plagioclase and clinopyroxene is on or near the liquidus at pressures between 5 and $8 \mathrm{kbar}$, suggesting this liquid could have formed from more primitive magmas or from peridotite at $15-25 \mathrm{~km}$ depth in the presence of small (about 2\%) amounts of $\mathrm{H}_{2} \mathrm{O}$. This leads to the postulate that exceptionally aluminous primary basaltic liquids reflect partial fusion of plagioclase Iherzolite under hydrous conditions. Rapid ascent, with degassing, would bring these liquids into the plagioclase primary phase volume, the resulting magmas being very coarsely phyric.

Other controlling factors on primary magma compositions are the depth and degree of partial fusion, which in turn depend on the geothermal gradient. An average gradient of $45^{\circ} \mathrm{C} / \mathrm{km}$ may be calculated from 


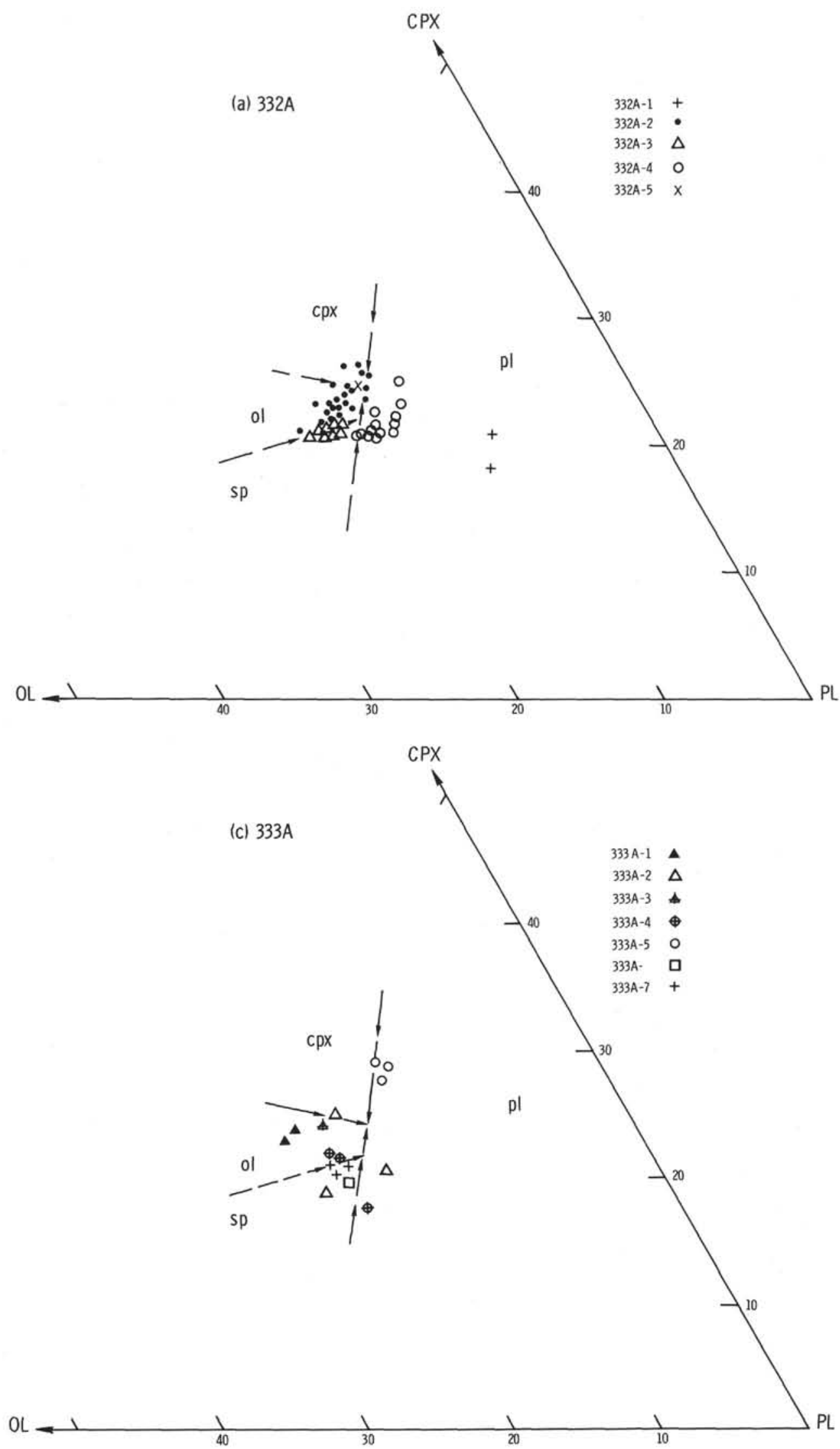

Figure 12. Normative compositions of Leg 37 basalts, showing individual magma groups, projected onto the plane olivineplagioclase-clinopyroxene in the "basalt" tetrahedron ol - cpx - plag - qz; low pressure cotectic boundaries are projected in accordance with petrographic evidence for liquidus phases and by analogy to experimentally melted basalts by Tilley et al. (1963); (a) 332A, (b) 332B, (c) 333A, and (d) 334 and 335. 


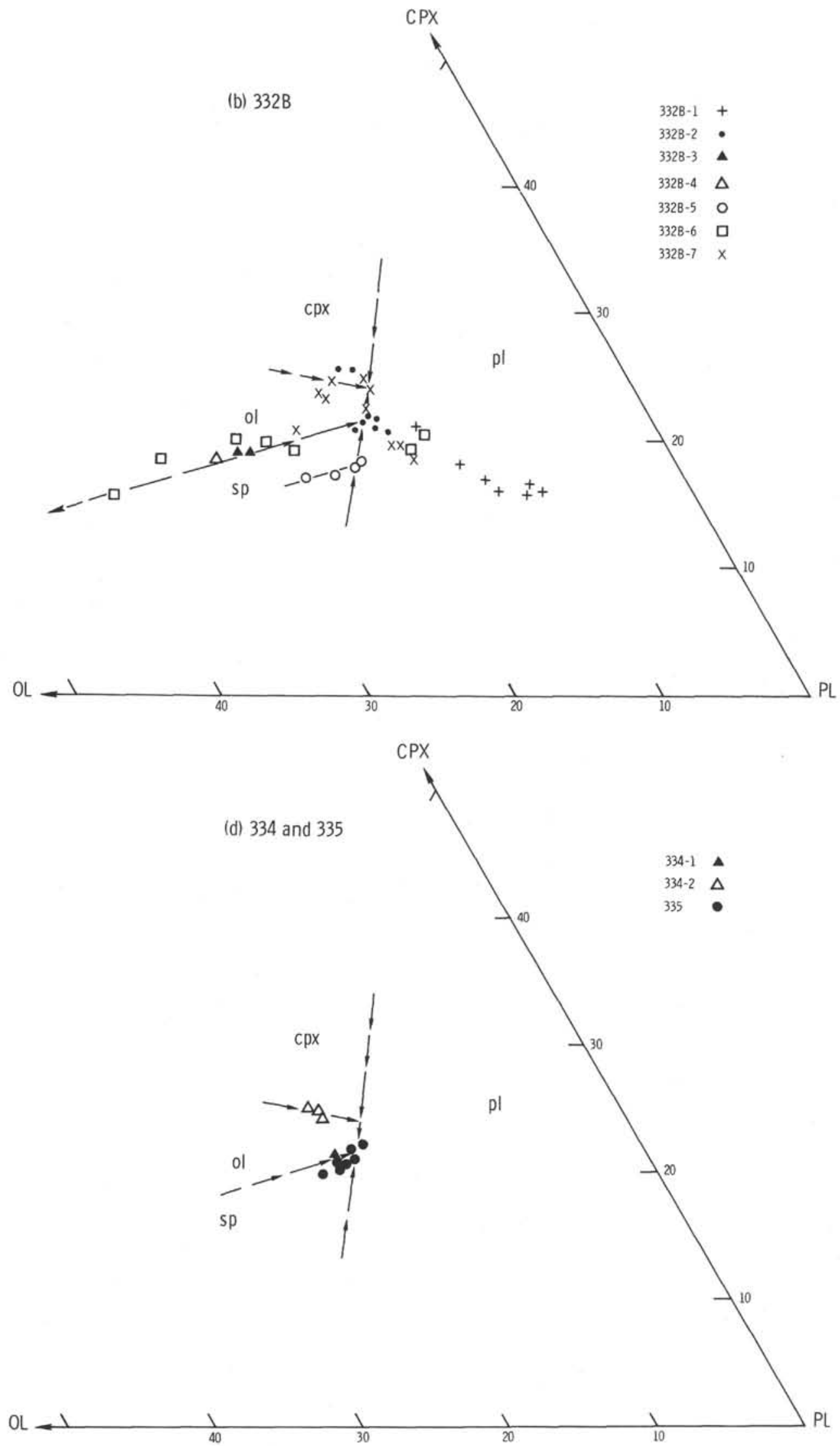

Figure 12. (Continued). 
the pressure/temperature conditions $\left(1215^{\circ} \mathrm{C}, 7.5 \mathrm{kbar}\right)$ of the 4-phase point for abyssal tholeiite (Flower et al., 1975). Given a constant gradient with time, the degree of partial fusion would depend on fluctuations in volatile content $\left(\mathrm{H}_{2} \mathrm{O}\right.$ would reduce the $\mathrm{P}$ and $\mathrm{T}$ of the peridotite solidus), or other changes in bulk composition of the source material. However, small changes in the gradient could result in significant changes in degree of fusion and might be attributable to random or intermittent sub-rift tectonic processes. We find no evidence of consistent long-term secular changes of magma composition (cf. Frey et al., 1974) between Sites 332 and 335 .

\section{Origin of the Plutonic Rocks}

Textural and chemical criteria suggest the plutonic rocks belong to a rhythmically layered cumulate complex, unless faulting has affected their relative juxtapositions. Presence of nannofossil chalk in the breccia and the absence of basaltic lava clasts suggest that the coarse-grained complex was tectonically uplifted to the floor of the median rift prior to eruption of the overlying basalts.

Although emplaced diapirically, the plutonic rocks are unlikely to be mantle material. Their inferred average sonic velocity of $6.88 \mathrm{~km} / \mathrm{sec}$ (Hyndman, Chapter 11, this volume) is appropriate for layer 3 materials. Indications of their relatively deep-seated formation (e.g., presence of orthopyroxene) and probable emplacement in the median rift zone suggest that the high level position of the body is anomalous. More usually, plutonic bodies of deeper origin (possibly at magma staging areas near the fusion zone) would rise to the base of layer 2 and contribute to a continuously accreting layer 3 together with other crystallized magma bodies occupying shallow-level subrift chambers. The depth of the layer $3 /$ layer 2 interface and the frequency of solid intrusions reaching the surface would depend on the physical properties of crystallizing magma (density, viscosity, gas content, etc.) and this overlying crust (permeability, strength, overall density, etc.) as evaluated for Iceland by Walker (1975).

\section{CONCLUSIONS}

1. Crustal construction along the median rift involves coeval eruption and intrusion of several magma types, characterized by different contents of $\mathrm{Al}, \mathrm{Ca}$, and LIL-elements, and formed by differential fusion of plagioclase therzolite at depths up to about $25 \mathrm{~km}$.

2 . The most primitive magmas have $100 \times \mathrm{Mg} /(\mathrm{Mg}$ $+\mathrm{Fe}^{+2}$ ) of 68-75 and, if olivine-phyric, phenocryst compositions are $\mathrm{Fo}_{84-90}$. Some have probably been erupted without significant fractionation, but most have been delayed at different levels beneath the rift, with development of chemical trends related to low pressure crystal fractionations.

3. High-alumina mafic magmas, with plagioclase on the anhydrous liquidus at 1 atm may have formed by partial fusion of plagioclase lherzolite under slightly hydrous conditions (about $2 \% \mathrm{H}_{2} \mathrm{O}$ ) at depths up to 20 $\mathrm{km}$.
4. Buildup of layer 2 was episodic, with cycles of eruption and high-level fractionation being related to spasmodic tectonic development of the rift.

5. No simple correlation is possible between Sites 332 and 333 . This may be due to extreme localization of eruption and magma flow, and/or to vertical displacement by faulting.

6. The plutonic complex at Site 334 is a cumulate body. It reflects: (a) fractional crystallization of trapped primitive LIL-depleted basaltic magma near (?) the zone of partial fusion, (b) slow cooling of the crystalline body, and (c) solid intrusion to the floor of the median rift.

7. The layer $3 /$ layer 2 interface may represent the level of compensation between newly crystalline magma, prevented from reaching the surface, and that magma erupted to the surface before final consolidation. Relative thickness of the two layers would thus be dependent on the physical properties of crystallizing magma and overlying crust.

\section{ACKNOWLEDGMENTS}

Thanks are due to G. Bullen and P. Watkins (Imperial College, London), H. Henning, P. van den Bogaard, R. Pier, and R.J. Starmer (Ruhr-Universität, Bochum) for assistance with X-ray fluorescence and wet chemical analysis; P. Suddaby (Imperial College), Drs. M. Engl and J. Sommerauer (E.T.H., Zürich) for help with electron microprobe work; and Prof. H. Puchelt (Universität, Karlsruhe) for $\mathrm{CO}_{2}$ analyses. P.T.R. received financial support from the Humboldt Stiftung (BRD), and M.F.J.F., H.-U.S., and W.O. were supported by Deutsche Forschungsgemeinschaft. M.F.J.F. is grateful to Prof. J. Sutton for use of laboratory facilities at Imperial College. We thank Prof. W. Schreyer (Bochum) for his continued interest and support for the project.

\section{REFERENCES}

Cann, J.R., 1970. Rb, $\mathrm{Sr}, \mathrm{Y}, \mathrm{Zr}$, and $\mathrm{Nb}$ in some ocean floor basaltic rocks: Earth Planet. Sci. Lett., v. 10, p. 7-11.

Engel, A.E., Engel, C.G., and Havens, R.C., 1965. Chemical characteristics of ocean basalts and the upper mantle: Geol. Soc. Am. Bull., v. 76, p. 716-735.

Flower, M.F.J., Schmincke, H.-U., and Thompson, R.N., 1975. Phlogopite stability and the ${ }^{87} \mathrm{Sr} /{ }^{86} \mathrm{Sr}$ step in basalts along the Reykjanes Ridge: Nature, v. 254, p. 404-406.

Frey, F.A., Bryan, W.B., and Thompson, G., 1974. Atlantic Ocean floor: geochemistry and petrology of basalts from Legs 2 and 3 of the Deep Sea Drilling Project: J. Geophys. Res., v. 79, p. 5507-5527.

Green, D.H., 1970. The origin of basaltic and nephelinitic magmas: Leicester Lit. Phil. Soc. Trans., v. 64, p. 26-54.

Green, D.H. and Ringwood, A.E., 1967. The genesis of basalt magmas: Contrib. Mineral. Petrol., v. 15, p. 103-190.

Kushiro, I. and Thompson, R.N., 1972. Origin of some abyssal tholeiites from the Mid-Atlantic ridge: Carnegie Inst. Wash. Yearbook, v. 71, p. 357-362.

Melson, W.G., Vallier, T.L., Wright, T.L., Byerly, G., and Nelen, J., in press. Chemical diversity of abyssal volcanic glass erupted along Pacific, Atlantic and Indian Ocean seafloor spreading centers: J. Geophys. Res. (Woollard Symposium Vol.).

Nicholls, G.D., 1965. Basalts from the deep ocean floor: Mineral. Mag., v. 34, p. 373-388.

O'Hara, M.J., 1968a. Are ocean floor basalts primary magma?: Nature, v. 220, p. 683-686. 
1968b. The bearing of phase equilibria studies in synthetic and natural systems on the origin and evolution of basic and ultrabasic rocks: Earth Sci. Rev., v. 4, p. 69133.

1973. Non-primary magmas and dubious mantle plume beneath Iceland: Nature, v. 243, p. 507-508.

Pearce, J.A. and Cann, J.R., 1971. Ophiolite origin investigated by discriminant analysis using $\mathrm{Ti}, \mathrm{Zr}$, and $\mathrm{Y}$ : Earth Planet. Sci. Lett., v. 12, p. 339-349.

Philpotts, J.A. and Schnetzler, C.C., 1970. Phenocryst-matrix partition coefficients for $\mathrm{K}, \mathrm{Rb}, \mathrm{Sr}$ and $\mathrm{Ba}$ with application to anorthosite and basalt genesis: Geochim. Cosmochim. Acta, v. 34, p. 307-322.

Ridley, W.I., Rhodes, J.M., Reid, A.M., Jakes, P., Shih, C., and Bass, M.N., 1974. Basalts from Leg 6 of the Deep Sea Drilling Project: J. Petrol., v. 15, p. 140-159.

Roeder, P.L. and Emslie, R.F., 1970. Olivine-liquid equilibrium: Contrib. Mineral. Petrol., v. 29, p. 275-289.
Tilley, C.E., Yoder, H.S., and Schairer, J.F., 1963. Melting relations of basalt: Carnegie Inst. Wash. Yearbook, v. 62, p. 77-84.

Tilley, C.E., Thompson, R.N., and Lovenbury, P.A., 1972. Melting relations of some oceanic basalts: Geol. J., v. 8, p. 59-64.

Wright, T.L. and Doherty, P.C., 1970. A linear programming and least-squares computer method for solving petrologic miximg problems: Geol. Soc. Am. Bull., v. 81, p. 19952008.

Wright, T.L. and Fiske, R.S., 1971. Origin of the differentiated and hybrid lavas of Kilauea Volcano, Hawaii: J. Petrol., v. 12, p. 1-65.

Walker, G.P.L., 1975. Eruptive mechanisms in Iceland. In Kristjansson, D. (Ed.), Geodynamics of Iceland and the N. Atlantic Area: p. 189-201. 